\title{
Paraoxonases Activities and Polymorphisms in Elderly and Old-Age Diseases: An Overview
}

\author{
Débora Levy ${ }^{1}$, Cadiele Oliana Reichert ${ }^{1}$ and Sérgio Paulo Bydlowski ${ }^{1,2,3, *}$ \\ 1 Genetic and Molecular Hematology Laboratory (LIM31), Hospital das Clínicas, Faculdade de Medicina, \\ Universidade de Sao Paulo, São Paulo 05419-000, SP, Brazil; d.levy@hc.fm.usp.br (D.L.); \\ kadielli@hotmail.com (C.O.R.) \\ 2 Center of Innovation and Translacional Medicine (CIMTRA), Department of Medicine, Faculdade de \\ Medicina, Universidade de Sao Paulo, São Paulo 05419-000, SP, Brazil \\ 3 Instituto Nacional de Ciencia e Tecnologia em Medicina Regenerativa (INCT-Regenera), CNPq, \\ Rio de Janeiro 21941-902, RJ, Brazil \\ * Correspondence: spbydlow@usp.br
}

Received: 20 March 2019; Accepted: 19 April 2019; Published: 2 May 2019

\begin{abstract}
Aging is defined as the accumulation of progressive organ dysfunction. There is much evidence linking the involvement of oxidative stress in the pathogenesis of aging. With increasing age, susceptibility to the development of diseases related to lipid peroxidation and tissue injury increases, due to chronic inflammatory processes, and production of reactive oxygen species (ROS) and free radicals. The paraoxonase $(\mathrm{PON})$ gene family is composed of three members (PON1, PON2, PON3) that share considerable structural homology and are located adjacently on chromosome 7 in humans. The most studied member product is PON1, a protein associated with high-density lipoprotein with paraoxonase/esterase activity. Nevertheless, all the three proteins prevent oxidative stress. The major aim of this review is to highlight the importance of the role of PON enzymes in the aging process, and in the development of the main diseases present in the elderly: cardiovascular disease, diabetes mellitus, neurodegenerative diseases, and cancer.
\end{abstract}

Keywords: aging; paraoxonase; PON; lipids; lipid peroxidation; heart disease; atherosclerosis; diabetes; cancer; neurodegenerative diseases

\section{Introduction}

Over the years, several theories have emerged to better explain the aging process. Among them, the influence of oxidative stress on aging has received great attention. It is based on the fact that cell metabolism, even under physiological conditions, generates reactive bioproducts, free radicals and oxidizing metabolites. The unbalance between the generation of oxidative metabolites and the presence of antioxidants would be responsible for the initiation of the aging process. The oxidative damage generated by metabolites such as free radicals, Reactive Oxygen Species (ROS) and/or Reactive Nitrogen Species (RNS), and peroxides, compromises the structure and function of macromolecules (carbohydrates, lipids, proteins, and DNA) in both, the intracellular and extracellular microenvironments [1]. For example, polyunsaturated fatty acids peroxidation mediated by hydroxyl and peroxyl radicals produce highly reactive aldehydes such as trans-4-hydroxy-2-nonenal, malondialdehyde (MDA) and isoprostanes [2-4]. The amino groups as lysine and arginine react with the carbonyl groups of carbohydrates in a process called glycosylation, resulting in advanced glycation end products (AGEs). Major AGEs include hydroimidazolone, $\mathrm{N} \in$-carboxymethyl-lysine, pentosidine, and glucosepane [2,3]. Oxidative damage to DNA results in several mutagenic lesions including 2-hydroxy adenine, 8-oxoadenine, 5-hydroxycytosine, cytosine glycol, thymine, 
and glycol. The mutagenic consequences of oxidative stress on DNA are 8-oxo-7,8-dihydro-guanine and 8-oxo-7,8-dihydro-2' deoxyguanosine lesions, which can result in G-to-T transversion events [2,3].

Oxidized lipids are able to trigger cell signaling in several cell types and tissues. Their biological effects are dependent on extent of lipid peroxidation and concentration, different transduction pathways, and nature of oxidized lipids (oxidized phospholipids, oxysterols, prostaglandins) [5-13]. One of the enzymes that inhibit lipid peroxidation is the paraoxonase family, composed by paraoxonase- 1 (PON-1), paraoxonase-2 (PON-2) and paraoxonase-3 (PON-3). They are involved in several diseases in which lipid peroxidation is important, including chronic inflammatory processes caused by metabolic oxidative stress [14-16].

PON-1 is a key functional constituent of HDL particles; PON-2 is essentially found in mitochondria and endoplasmic reticulum while PON-3 is localized in HDL, mitochondria and endoplasmic reticulum [14-16]. Many studies have shown that the serum activity of PON-1 in individuals suffering from several diseases (ischemia, chronic kidney disease, morbid obesity, dyslipidemia), the esterase activity of the enzyme is considerably reduced. In addition, the administration of purified PON-1 itself was shown to reduce the development of inflammatory bowel disease and diabetes, both in animal model [17].

The elderly population is more susceptible to the oxidative damage generated by these molecules, due to the reduction of antioxidant molecules [18]. Older individuals have more difficulty in absorbing or producing certain nutrients, such as antioxidant vitamins (vitamin $A$ and $\beta$-carotene, vitamin $C$ and E) as well as polyphenolic compounds [19]. By genetic factors or environmental influence, there is a change in the detoxification and inactivation of toxic metabolites and xenobiotics by enzymes of the CYP450 complex and glutathione peroxidase [20]. Besides, with increasing age, a decrease in the activity of antioxidant enzymes such as catalase (CAT), superoxide dismutase (SOD) and paraoxonases (PONs), is observed [21]. The altered function of these enzymes leads to changes in gene expression, metabolic control and maintains cells in senescence [22]. Uncontrolled redox system promotes a vicious cycle with high and chronic inflammation and intense lipid peroxidation of membranes and tissues, thus decreasing the quality of life of the elderly population [23].

The diseases with a higher incidence and prevalence in the elderly population include type 2 diabetes mellitus, obesity, dyslipidemia, atherosclerosis, cardiovascular disease, acute myocardial infarction, hypertension, peripheral vascular disease, Alzheimer's disease, Parkinson's disease, age-related macular degeneration, multiple sclerosis, epilepsy, depression and cancer [24-28].

The aim of this paper is to review the pathophysiological role of paraoxonases: PON-1, PON-2 and $\mathrm{PON}-3$, in the development of diseases related to aging and lipid peroxidation, mainly in atherosclerosis and cardiovascular diseases, diabetes mellitus, neurodegenerative diseases (Alzheimer's disease, Parkinson disease, multiple sclerosis) and cancer.

\section{The Paraoxonase Family}

The three human PON genes are clustered on the long arm of chromosome 7 (7q21.31-q22.1). All of them have nine exons and share around $70 \%$ of homology at the nucleotide level and $60 \%$ of homology at the amino acid sequence [14,29]. In mammals, the comparative similarity of each of those three genes is higher and reaches $81-90 \%$ homology at the nucleotide sequence and $79-90 \%$ of homology at the amino acid sequence $[29,30]$. PON-1 can be differentiated from $P O N-2$ and $P O N-3$ by the three extra nucleotide residues in exon 1 [29-31]. Although the three enzymes have high homology to each other, each of them has its particular function, according to its location. However, all paraoxonases act to protect against oxidative damage and decrease endoplasmic reticulum stress. They also participate in the regulation of apoptosis, in non-specific immunity, and in the bioactivation of drugs [28].

PON-1 was first described in 1946 when Abraham Mazur reported an enzyme activity found in mammalian tissues which was capable of hydrolyzing organophosphate compounds [32]. This led to the initial identification of the human serum paraoxonase (PON-1) enzyme in the early 1950s by 
Norman Aldridge. Initially, the enzyme was referred to as "A"-esterases, but later became known as paraoxonase due to its ability to detoxify the substrate paraoxon, the toxic metabolite of the commonly used insecticide parathion [32-34].

The three paraoxonase (PON-1, PON-2 and PON-3) enzymes are able to, in vitro, hydrolyze aromatic lactones, as well as products derived from the enzymatic or non-enzymatic metabolism of both, arachidonic and docosahexaenoic acid [35-38]. However, although all three PON types are named paraoxonase, only PON-1 has the ability to hydrolyze organophosphates [35]. The PON-1 can hydrolyze toxic oxidative metabolites of organophosphorus insecticides (parathion, diazinone and chlorpyrifos), nerve agents (sarin and soman), aromatic esters, and aliphatic lactones. The PON-2 has the ability to hydrolyze and inactivate $\mathrm{N}$-acyl-homoserine lactones, which are quorum signs of pathogenic bacteria. The PON-3 hydrolyzes drug metabolites and is involved in the multidrug resistance phenotype [36-38] (Figure 1).

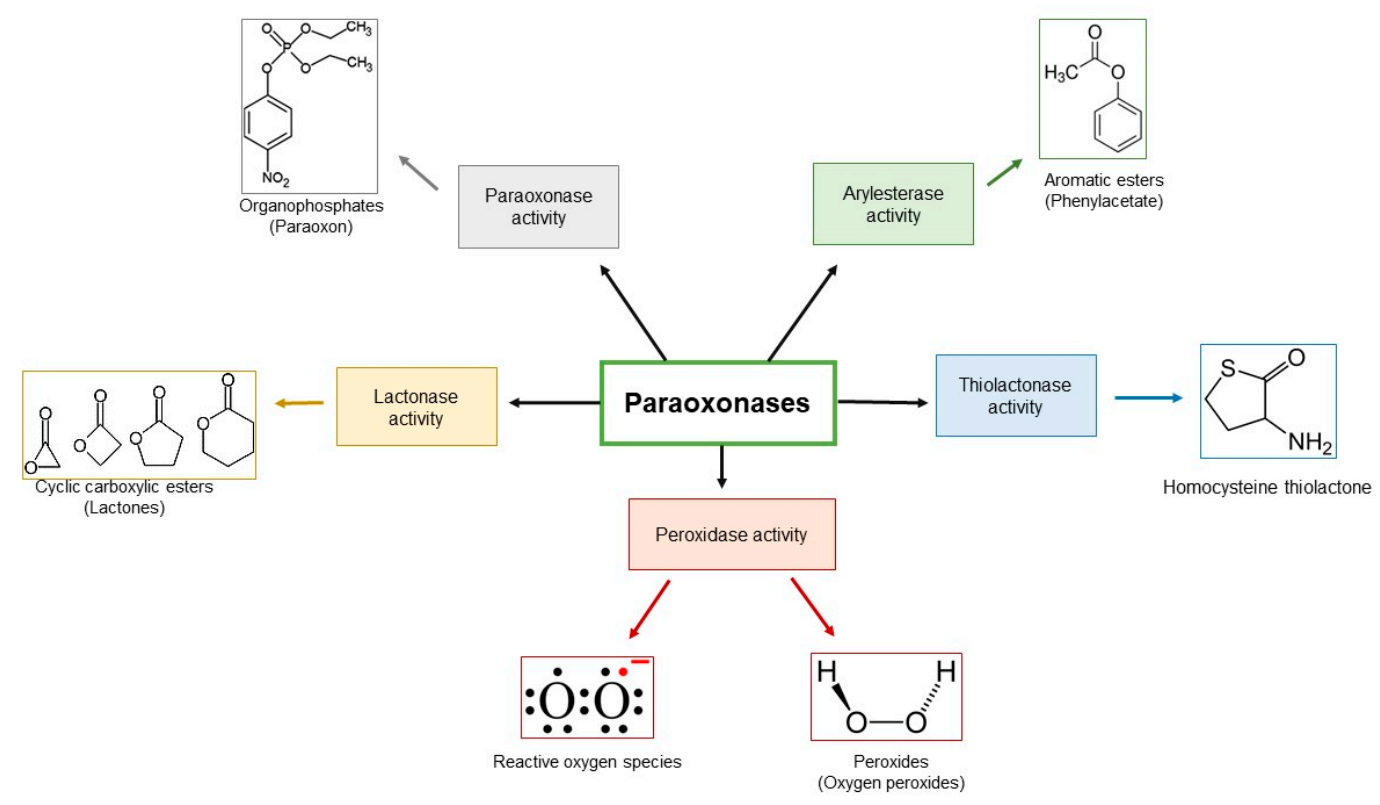

Figure 1. Paraoxonases activities and substrates.

\subsection{Paraoxonase-1}

PON-1 is a calcium-dependent enzyme consisting of 354 amino acids with a molecular mass of about $43 \mathrm{kDa}$, synthesized in the liver [34]. Structural analysis using X-ray crystallography revealed the three-dimensional structure of PON-1. It is composed of six-bladed $\beta$-propeller, forming a central tunnel which contains two calcium ions $\left(\mathrm{Ca}^{2+}\right)$ [39]. Each calcium ion, depending on its location within the enzyme, plays an important role in the activity of PON-1. The calcium ion located more deeply within the tunnel has a structural role and maintains the conformational stability of the enzyme [39]. The other calcium ion at the bottom of the active site cavity has a catalytic role and is important for substrate positioning and activation of the ester bond [39]. Three helices are located above the active site of PON-1, named $\mathrm{H} 1, \mathrm{H} 2$ and $\mathrm{H} 3$, where $\mathrm{H} 1$ and $\mathrm{H} 2$ have functions in the PON-1-HDL interactions [34,39].

PON-1 has paraoxonase, arylesterase, and lactonase activities, being one of the important enzymes associated with high density lipoproteins (HDL) [40]. In fact, PON-1 is one of the enzymes responsible for the antioxidative activity of HDL, that includes lecithin-cholesterol acyltransferase and platelet-activation factor acetyl-hydrolase [40]. Although in general PON-1 circulates associated with HDL, it is also found, in a lesser extent, in very low density lipoproteins (VLDL) and chylomicrons in the postpandrial period [41,42]. The stable and high affinity binding between PON-1 and HDL requires the interaction with apoA-I [43]. The high lipolactonase activity of PON-1 is stimulated by apoA-I, 
and free PON-1 has lactonase activity lower than PON-1 associated with HDL [43,44]. HDL-bound PON-1 is transported and distributed to the cell membranes, in several tissues and organs (Figure 2). In this way, it exerts a primordial role against lipid peroxidation of membranes and low-density lipoprotein (LDL) [34,45], as well as the generation of free radicals resulting from the activation of inflammatory processes and oxidative stress [45].

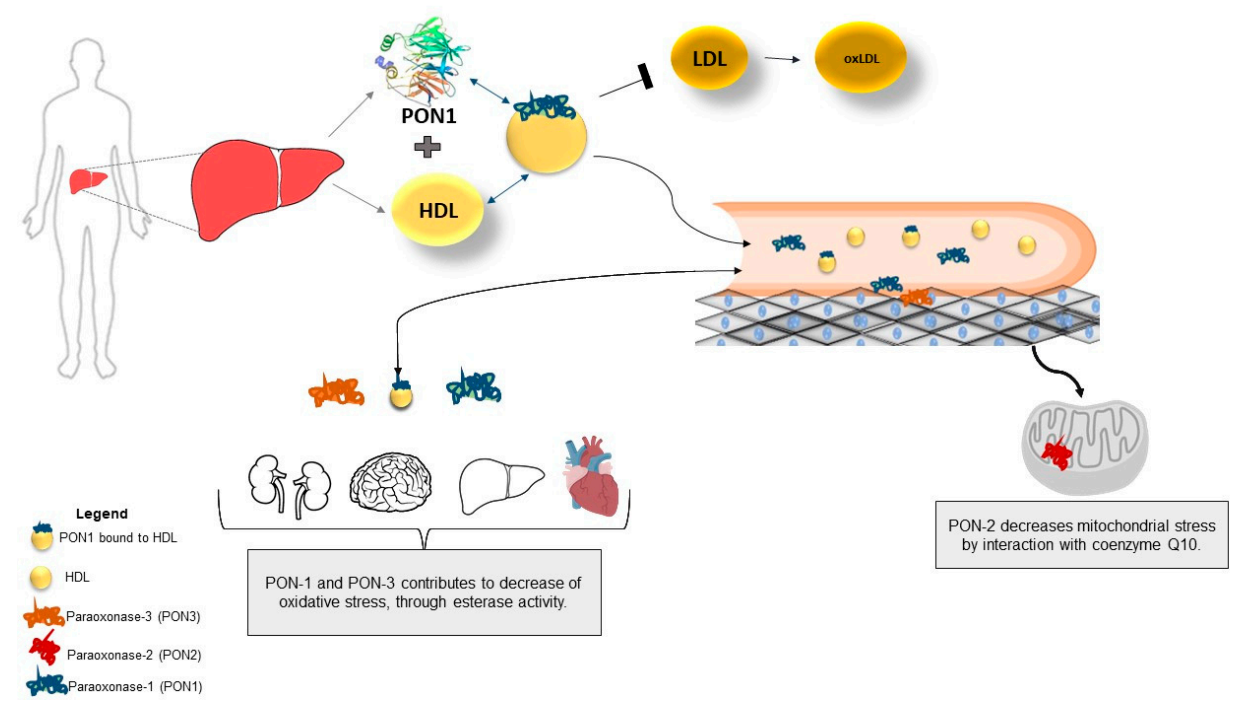

Figure 2. Location and distribution of PON-1, PON-2 e PON-3 in organs and tissues.

The enzymatic activity of PON-1 has several interferences, and the micro- and macro-environment may contribute to reduce the activity of the enzyme, as well as, a mutation and/or presence of single-nucleotide polymorphism (SNP) in the promoter and/or codon region of the PON-1 gene [46]. Currently, the enzyme is known to have lower serum arylesterase activity in individuals with higher oxidative stress, it is a protective enzyme against both tissue and lipid damage caused by oxidative stress and its bioactive derivatives [47-53]. PON-1 has peroxidase activity, leading to the neutralization of hydroperoxides of fatty acids, cholesteryl ester hydroperoxides and hydrogen peroxide $\left(\mathrm{H}_{2} \mathrm{O}_{2}\right)$ [54] . The high expression of PON-1 contributes to the hepatoprotection against the peroxides generated in the inflammatory process [55].

PON-1 also acts in the hydrolysis of homocysteine thiolactone (HTL), a product of homocysteine (Hcy) metabolism and a poor substrate for PON-1. Homocysteine is part of the sulfur amino acid group, and its formation occurs by the demethylation of methionine obtained from diet or the catabolism of homocysteine itself [56,57]. Hcy-thiolactone is a reaction product catalyzed by the enzyme methionyl tRNA synthetase. Hcy-thiolactone is a reactive metabolite that modifies protein lysine residues in a process known as N-homocysteinylation. Plasma Hcy-thiolactone and the N-homocysteinylation protein are present in the human body and are greatly elevated in hyperhomocysteinemia of genetic or nutritional origin [57].

It was hypothesized that vascular disease mediated by Hcy is due to its toxicity by its conversion to Hcy-thiolactone, which then modifies the proteins to generate N-Hcy-protein, leading to cell death, altered vessel structure, chronic inflammation, autoimmune response and atherosclerosis, as well as the development of thrombosis and neurological diseases [58-60]. N-Homocysteinylation of HDL changes its structure, the conformation and properties of apolipoprotein, decreasing its antioxidant properties [58]. In vivo and in vitro studies demonstrate that PON-1 protects against the damage caused by hyperhomocysteinemia associated with the development of atherosclerosis and vascular endothelial dysfunction [61], age-related macular degeneration [62], multiple sclerosis [63] and cancer [28]. In an animal model, PON-1 has been shown to be protective against the neurotoxicity of Hcy-thiolactone by hydrolyzing it in the brain [64]. 


\section{PON-1 Polymorphisms}

Eight SNPs have been identified on the promoter region and 176 within the human PON-1 gene sequence. Among the SNPs described for PON-1 gene, two gained special attention due to the association between paraoxonase, arylesterase and lactonase activities of the different alloenzymes [39]. The arginine aminoacid at position 192 of PON-1(Q192R; gln191 to arg) specifies high-activity plasma paraoxonase, whereas glutamine at this position specifies a low-activity variant [65]. The glutamine determines the A allozyme and the arginine amino acid determines B allozymes of PON-1 [66]. The exchange of a leucine at position 55 by a methionine (polymorphism L55M) increases paraoxon activity over 50\% in the homozygous form (MM) compared with the LL and LM [67]. Moreover, 55L maintains stability of the PON-1 protein structure [68]. In addition, frequencies of Q192R and L55M alleles are different between populations. The frequency of alleles Q192 and L55 is higher in Caucasian populations, while in Asian populations the allele R192 is higher, and the allele M55 is lower [28]. Moreover, the enzymatic activity of PON-1 varies according to the populations, as well as the susceptibility to develop certain diseases related to paraoxonases [28]. The HTLase activity of PON-1 is modified by polymorphisms at position 55 and 192. Individuals carrying the alleles both L55 and R192 have higher homocysteine lactonase activity than individuals carrying PON-1 M55 and Q192 alleles [58]. Other three SNPs (G-907C, A-162G and C-108T) in the promoter sequence of the PON-1 gene were associated with considerable differences in PON-1 concentration and activity [39].

\subsection{Paraoxonase-2}

The human PON-2 gene is located on the long arm of chromosome 7 (7q21.3-q22.1) and is adjacent to the family members $P O N-1$ and $P O N-3$. The genomic structure of $P O N-2$ is composed of nine exons that encode a protein of 355 amino acids, with approximately $40-43 \mathrm{kDa}$; such structure presents $65 \%$ similarity with PON-1. The difference in the mass of PON-2 is due to the presence of an additional glucose residue $(43 \mathrm{kDa})$ in the structure of the enzyme. However, there is no difference in enzyme function [69]. PON-2 is an intracellular protein and, unlike PON-1 or PON-3, it is not present in plasma. Based on a phylogenetic analysis, PON-2 is the oldest member of this gene family, and PON-1 and PON-3 have evolved from PON-2 [29,70].

PON-2 is located in the membrane of the mitochondria and in the endoplasmic reticulum. Due to its location, expression and lactonase activity in all tissues, it has gained special attention in studies related to oxidative stress and lipid peroxidation. Its expression is upregulated under cellular oxidative stress and reduced superoxide release from the inner mitochondrial membrane. By its anti-oxidative effect, PON-2 reduces cellular oxidative damage and influences redox signaling, which promotes cell survival and decrease of apoptosis [71-73]. PON-2 mRNA is expressed in almost all human tissues, with the highest expression in the liver, lungs, placenta, testicles and heart [74]. PON-2 mRNA is also found in the cells of the arterial wall, including endothelial cells, smooth muscle cells and macrophages [74-76]. Among the three paraoxonase enzymes, PON-2 is the only one expressed in nervous tissues [69]. Studies in mice have shown that both PON-2 concentration, mRNA expression and lactate activity of the enzyme are different between males and females. The high concentration of PON-2 in brain (in females, about three times higher than in males), protects neurons and astrocytes against oxidative stress toxicity and lipid peroxidation [77]. Furthermore, the antioxidant, anti-inflammatory and protective effect of PON-2 has been shown in intestinal epithelial cells $[78,79]$, in human vascular endothelial cells, lung epithelial carcinoma cells and in Caco-2/15 intestinal epithelial cells [78-80]. In vitro studies suggest that PON-2 can regulate the activity of epithelial sodium $\left(\mathrm{Na}^{+}\right)$channels by modulating its intracellular traffic and surface expression. Epithelial sodium channels are involved in physiological processes such as mechanosensitivity, locomotion, nociception, termination of seizures, detection of pheromones, release of fluid in the airways, among others [81].

PON-2 polymorphisms. The most important and studied polymorphisms of the PON-2 gene are an Ala/Gly substitution at position 148, and a Ser/Cys substitution at position 311 [82]. 


\subsection{Paraoxonase-3}

The PON-3 gene was described in 1996 by Primo-Parmo et al., [29], and has about $85 \%$ of similarity with PON-1 gene. PON-3 is a 40-kDa glycoprotein mainly synthesized by the liver. Like PON-1, PON-3 is found in circulation tightly bound to HDLs. PON-3 has high lactonase activity, low arylesterase activity, and no paraoxonase activity $[16,83,84]$. The activity of PON-3 has been reported to be calcium-dependent, like PON-1. PON-3 hydrolyzes aromatic lactones and lactones composed of five and/or six membered rings with aliphatic substituent groups, such as statin prodrugs. However, simple lactones or lactones with polar substituent groups are not hydrolyzed by PON-3 [16]. PON-3 expression has been described in endoplasmic reticulum of intestinal cells and more recently in mitochondria of selected tissues [33]. During oxidative stress in mouse macrophage PON-3 expression decreases, while $\mathrm{PON}-2$ expression increases, highlighting a stronger antioxidant role of PON-2 in relation to PON-3 [84]. Interestingly, in vitro, PON-3 was described to protect LDL from copper-induced oxidation [16].

PON-3 polymorphism. There are very few studies on polymorphisms of the PON-3 gene. The main polymorphisms in PON-3 described so far are the c.449G > A, the SNPs A10340C and A2115T, and the PON-3 intronic variant INS2+3651 (A > G) (rs10487132) [83].

\section{Paraoxonases Association with Diseases}

Paraoxonases activities and polymorphisms have been studied and often associated with several different diseases: chronic metabolic syndrome, chronic liver impairment, psoriasis, systemic lupus erythematosus, hearing loss, sporadic amyotrophic lateral sclerosis and obesity. It seems that PON also have a role in infectious diseases. Infectious diseases are often associated with oxidative stress and an inflammatory response [85-87].

The acute-phase response (APR) to an infection generates metabolites that alter the composition and structure of HDL: depletion of cholesterol esters and an enrichment in free cholesterol, triglycerides, and free fatty acids. Overall, these changes cause HDL particles to lose some of their anti-atherogenic and anti-inflammatory properties and may even become pro-atherogenic and pro-inflammatory [88]. Thus, constant infections can lead to the development of heart disease. For instance, Helicobacter pylori infection is considered to be a risk factor for atherosclerosis. During the infection, increase in the levels of lipid hydroperoxides and PON-1 esterase activity is reduced $[89,90]$.

Another example is the HIV-1 infection. It has been shown that PON-1 arylesterase activity correlates positively with the total number of $\mathrm{CD} 4+\mathrm{T}$ cells; moreover, in individuals with high viral load PON-1 activity is reduced, while after reduction of viral load per treatment, PON-1 activity increases [51]. In addition, PON-3 concentrations increased about three times in HIV-infected patients with oxidative stress when compared with healthy controls. However, no significant association was seen between serum PON-3 concentrations and CD4+ T-cell, CD8+ T-cell, the CD4+/CD8+ ratio, and the plasma HIV-1 viral load [91].

\section{Paraoxonases and Aging}

Serum PON-1 concentration and activity are very variable between individuals. The enzymatic serum activity of PON-1 in healthy humans is low in early life, increases over time, remains stable throughout adult life, and decreases in the elderly $[13,65]$.

During the process of aging, the equilibrium between redox state and antioxidant agents changes [92]. These alterations interfere with cellular and tissue regeneration [93]. The imbalance in the redox state may be associated with genetic and/or epigenetic alterations with increase of pro-inflammatory cytokines, failure to capture and use glucose as energy source, and increased oxidation of fatty acids and lipids [94,95]. Changes related to oxidative lipid metabolism are one of the main causes of the development of chronic diseases in the elderly as well as the decrease in longevity [96]. These changes may be due to genetic mutations, a sedentary lifestyle, or an unbalanced diet (rich in fats, sugars and carbohydrates), Inflammation, change in liver and renal functions, 
factors related to social interaction and the environment [97]. Among the protective factors against aging, the antioxidant enzymes are of importance, as previously described.

The association between PON-1 enzyme and cell aging was evidenced by Lee et al., [98]. PON-1 gene expression of human microvascular endothelial cells in culture was inhibited with interfering RNA. It was observed that cell viability was reduced, and cells entered into senescence, with increased $\beta$-galactosidase and flattened cellular morphology. Another important result was the high increase of protein hydroperoxides. Protein hydroperoxides inhibit thiol-dependent cysteine proteases and protein tyrosine phosphases [98]. These proteases break down proteins damaged by oxidative stress in cells, tissues and plasma, and participate in the activation and propagation in signaling pathways of the redox system. Therefore, when these proteases are decreased, the oxidative signaling is increased, contributing to the triggering of the aging process [98].

In a study with 1,932 Danish individuals, aged 47 to 93 years, three polymorphisms of the PON-1 enzyme, L55M, R192Q, T-107C, were investigated and related to mortality [99]. It was concluded that there was no difference between the genotypic and haplotypic distribution among the age groups evaluated. However, individuals with homozygous genotype for 192RR had a lower survival rate compared to 192QQ homozygous individuals, more pronounced in women. However, the meta-analysis conducted by Caliebe et al., [100], composed of 9580 individuals in different populations did not demonstrate an association between the $\mathrm{R}$ allele and longevity; however, the authors pointed out that due to the influence of different genetic and/or environmental factors, it is unlikely that the phenotypic effects of the genes are identical in different populations.

Another polymorphism of PON-1, the SNP rs662 (G > A), was associated with human longevity and decreased serum lipid concentration [101]. The alteration of lipid profile, increase of triglycerides and LDL-cholesterol are factors that decrease longevity and are predictors of many diseases related to lipid oxidation and increase of oxLDL [101]. In a study with 446 healthy older-old 'Super-Seniors' (individuals 85 or older who have never been diagnosed with cancer, cardiovascular disease, dementia, diabetes or major pulmonary disease), the genes that "protect" against aging and are related to the lipid profile were evaluated [102]. It was found that Super-Seniors did not carry an APOE 4 allele or an HP2 allele of haptoglobin, and that the lipid profile and cholesterol levels remained stable, as PON-1 and apoE. ApoE, as PON-1, play an important role in lipid metabolism and protection of lipid peroxidation [102]. Moreover, a synergism was found between the APOE 44 allele and the PON-1 L55M SNP, since individuals carrying both the APOE 44 allele and the $55 \mathrm{MM}$ homozygote genotype had a decrease of the arylesterase activity [102].

Although several studies did not associate the esterase activity to longevity, it was shown in individuals aged 20 to 81 years of both genders that a decrease in the arylesterase activity of PON-1 was proportional to the increase in the susceptibility of oxidation of the LDL (oxLDL) due to the increase of free radicals in the plasma. PON-1 was categorized as a longevity gene [103].

In the aging process, metabolic rates decrease; DNA is exposed to free radicals, peroxides and reactive oxygen species; the DNA methylation process and acetylation of chromatin increase with age, and as a consequence, there is a significant reduction of protein synthesis and accumulation of progressive organic dysfunction [104]. Sirtuins (STR) have become famous molecules able to retard aging and decrease age-related disorders [105]. They are located in several cell compartments: nucleus, cytoplasm and mitochondria [106]. These proteins protect cells against oxidative stress, regulate glucose/lipid metabolism, and promote the deacetylation stability of various substrates by regulating cell cycle processes, proliferation, and apoptosis [107]. In $\mathrm{H}_{2} \mathrm{O}_{2}$-producing cells under oxidative stress, mitochondrial PON-2 and STR2 proteins are overexpressed; this leads to a decrease in the damage caused by the peroxides, maintaining the mitochondria homeostasis [108]. In THP-1 monocytic cell line incubated with HDL isolated from healthy individuals, SIRT1 protein expression is increased compared with cells incubated with HDL from patients with coronary disease. Moreover, HDL from coronary disease patients has decreased PON-1 activity compared with that from healthy controls [109]. 
Interestingly, elderly individuals bearing mutant allele $(\mathrm{G})$ for both rs7895833 (A > G) and rs7069102 $(C>G)$, polymorphisms encoding the STR1 protein, had lower levels of PON-1 [110].

\section{Paraoxonase and Cardiovascular Diseases}

Aging is a risk factor for atherosclerosis. Atherogenesis is a slow and progressive process that begins in the first decades of life until complete plaque formation at the end of adulthood/onset of aging [111]. The process is multifactorial and includes alterations, dysfunction and activation of endothelial cells, smooth muscle cells and macrophages in the arterial wall, beside lipoproteins and humoral factors. Inflammatory cells and inflammatory mediators are also present at all stages of plaque formation [112]. The arterial permeability is increased, reactive oxygen species are generated, and inflammatory adhesion proteins and chemokines are expressed. The endothelium permeability allows an influx of plasma components, in the subendothelial area, where lipoproteins undergo several changes, including oxidation [113]. Chemokines and adhesion proteins promote the recruitment of monocytes that take up modified lipoproteins, accumulate lipids (mainly cholesterol esters) and are converted into macrophagic foam cells that form fatty streaks. These early lesions may rapidly grow in the presence of hypercholesterolemia or other risk factors, leading to the fibrous plaque [114-116].

The development of atherosclerosis also involves the oxidation of LDL, producing a pro-inflammatory bioactive particle necessary for the onset and formation of atheroma plaque [115-117]. With aging, there is an increase in ROS production from disruption of endothelial cells and tissues favoring oxidation, glycosylation, carbamylation and glycoxidation of plasma LDL [118]. On the other hand, HDL has been considered atheroprotective, due to its participation in the reverse cholesterol transport, where ApoA-1, the major apoprotein forming HDL, plays an important role by promoting the cholesterol efflux from macrophages. HDL is also known by its capacity to impair LDL oxidation, as stated before [118-120].

Descriptions relating paraoxonases to cardiovascular diseases began around 30 years ago with the association of decreased PON-1 activity with the development of atherosclerotic plaque [121]. Overexpression of PON-1 in mice increases approximately $30 \%$ the ability of HDL to mediate cholesterol efflux of J774 macrophages. It also caused an increase in the ability of macrophages to transfer cholesterol to ApoA-1, as well as increased both mRNA and ABCA1 protein expression, PPAR $\gamma$ and $\mathrm{LXR} \alpha$ pathway [122].

However, PON-1 is not the only paraoxonase enzyme involved in the transport of cholesterol by macrophages. High PON-2 and PON-3 expression favor macrophage cholesterol efflux and impair oxidation of LDL by lipid hydroperoxide hydrolysis and increase the antioxidant action of HDL in protecting LDL [123,124]. As stated before, HDL is described as having the antioxidant ability to prevent or delay the oxidation of LDL due to proteins associated with its surface, such as PON-1, which can prevent the oxidation of HDL, as well as LDL [125-137]. Again, it is important to note that both PON-1 and PON-3 are components of HDL and that they reduce the atherogenicity of lipoproteins through of hydrolyzing of lipolactones [138,139]. As a result, the uptake of atherogenic lipoproteins by macrophages and the formation of foam cells is reduced [140]. The action of PON-1 and PON-3 can occur in both the vascular and plasma membranes, increasing the action spectrum of the enzyme $[141,142]$. It has been speculated that the mechanism by which PON-1 delays LDL oxidation involves the hydrolysis of the truncated fatty acid phospholipid hydroperoxides, cholesterol esters, and triglycerides, resulting in the production of lysophospholipids, cholesterol, diglycerides and oxidized fatty acids. However, these mechanisms have not yet been fully described [143].

The atheroprotective capacity of paraoxonase enzymes has been also attributed to the neutralization of compounds generated by mitochondria. The enzymes PON-2 and PON-3 interact with mitochondria coenzyme Q10, leading to decreased oxidative stress $[143,144]$. As a result, ROS-triggered mitochondrial apoptosis and cell death are reduced, decreasing atherosclerotic plaque development $[143,144]$.

In PON-3 knockout mice, PON-3 deficiency resulted in compromised mitochondrial respiration due to decreased activity of complexes II, III and IV, which led to increased mitochondrial superoxide 
levels and increased ROS production. Another interesting result of this study was the increase in the expression of Mcp-1 and interleukin-6 (IL-6) and increase in calcified atherosclerotic plaque by up to $60 \%$ [144].

The altered relationship between PON-2 and mitochondria can also be observed in acute myocardial infarction (AMI); the lack of oxygen and the increase in ROS production are the main factors for cardiac tissue necrosis. The production of reactive oxygen species in the mitochondria, due to ATP depletion, causes the death of cardiomyocytes, following myocardial ischemia-reperfusion injury (IRI) [145]. In an animal model, PON-2 protects against acute myocardial infarction by reducing mitochondrial dysfunction and oxidative stress in cardiomyocytes by the PI3K/Akt/GSK-3 $\beta$ pathway [146]. As previously mentioned, PON-2 is located on the inner membrane of mitochondria, and PON-2 deficiency alters mitochondrial function by decreasing both mitochondrial complex I-III activity and ATP levels. Next, mitochondrial oxidative stress increases after increasing mitochondrial superoxide production and lipid peroxidation and decreasing reduced glutathione levels [146].

In addition, it has been shown that inflammation, reactive oxygen species and lipid peroxidation products generated during oxidative stress could enhance tissue factor (TF) expression and procoagulant activity. TF is the initiator of the extrinsic coagulation pathway [147]. In an experiment with PON-2 (-/-) mice, in order to evaluate the relationship between PON-2 and coagulation, Ebert et al., [148], observed an increase in oxidative stress, endothelial dysfunction and the concentration of interleukin- 6 in the vasculature, as well as increased tissue factor activity in endothelial cells, in vitro. In this experiment it was also possible to verify that coagulation times were shortened and platelet procoagulant activity increased in PON-2 (-/-) mice. The reexpression of PON-2 in endothelial cells recovered the procoagulant state of rats. The authors concluded that the regulation of the redox state by the enzyme PON-2 regulates the activity of the tissue factor, preventing both activation of systemic coagulation and inflammation [148].

PON-1 polymorphisms seem also to affect the atherosclerotic process and cardiovascular disease. The G allele (rs662) in PON-1 gene was shown to be a risk factor for the development of arterial coronary disease in the Chinese population [149]. The GG and AG genotype and G allele of PON-2 (148 A/G) was associated with decrease in PON-1 activity and decrease of coronary heart disease in a Chinese population [150]. A study of 442 elderly patients with acute myocardial infarction followed up for a period of one year showed that patients with the C allele (S311C) of PON-2 gene had a worse prognosis when compared to patients without the $\mathrm{C}$ allele; that mortality risk was approximately 11 times higher [151]. It is important to note that this C311 polymorphism has been also associated with the development of coronary artery disease [152].

\section{Paraoxonases and Type 2 Diabetes Mellitus}

Oxidative stress and lipid peroxidation have been implicated as contributors to both the onset and progression of diabetes and its complications. The main consequences of long-term oxidative damage are the development of $\beta$-cell dysfunction, impaired glucose tolerance and mitochondrial dysfunction. By-products from oxidative stress activate several stress pathways such as NF- $\mathrm{kB}, \mathrm{JNK} / \mathrm{SAPK}$ and p38 MAP, which alter insulin signaling, intracellular and between cells, as well as contribute to peripheral insulin resistance in adipose and muscular tissues [153]. As mentioned previously, the paraoxonases exert various functions in order to reduce the oxidative environments.

In a study from Koren-Gluzer et al., [154], it was observed that PON-1-deficient mice (-/-), being fed a hypercaloric diet, develop peripheral resistance to insulin. The authors attributed this result to increased oxidative stress, increased p38MAPK activity, and decreased insulin-mediated tyrosine phosphorylation of insulin receptor substrate 1 (IRS-1); thereafter, there was a decrease in glucose uptake. After the addition of PON-1 to cultured myocytes in vitro, there was an increase in mRNA and protein expression of the glucose transporter GLUT-4. This increase was time- and PON-1 concentration-dependent. In addition, intracellular glycogen stores increased. These effects were mediated via the inhibition of the p38 MAPK pathway, which contributed to the reduction of IRS-1 
serine phosphorylation and IRS-1 tyrosine phosphorylation. Another interesting result described was the blocking of the SH group in PON-1, which partially decreased GLUT4 expression. However, a mutation in H115 abolished GLUT4 expression [154]. The H115 residue forms part of the catalytic center of the enzyme PON-1, along with two more amino acid residues, L69, V346. Together, these residues are responsible for the hydrolase activity of PON-1 [155]. In addition, in vitro, PON-1 protects $\beta$-cells against cytokine-induced cytotoxicity (IL- $1 \beta$, TNF- $\alpha$ and INF- $\gamma$ ), decreasing EROS, nitrous oxide levels and caspase-3 [156].

Changes in PON-2 have also been shown to influence the development of diabetes. In mice lacking the PON-2 gene showed to have a greater probability of gaining weight, developing obesity, as well as hypertrophy of adipocytes, glucose tolerance in fasting, decreased oxygen consumption, energy expenditure and mitochondrial dysfunction [157]. In patients with T2D, the daily intake of $2 \mathrm{~g}$ of eicosapentaenoic acid (EPA) was shown to be efficient for PON-2 expression increase and decrease of glycemic indexes [158].

Obesity, lipid oxidation and its comorbidities are associated with impaired cognitive performance, accelerated cognitive decline, and neurodegenerative pathologies, such as dementia in old age, and interventions targeting obesity in middle age may be beneficial in reducing cognitive risks associated with age [159]. Blood PON-1 arylesterase, paraoxonase, and lactonase activities were evaluated in patients with morbid obesity before and six months after Roux-en-Y Gastric Bypass (RYGB). Before surgery, patients had a lower concentration of PON-1, with no change in arylesterase and paraoxonase activities, and higher lactonase activity, compared with non-obese individuals. Lactonase activity decreased after surgery, which was associated with increased esterified cholesterol levels. However, no increase in both arylesterase and paraoxonase activities were observed after surgery $[160,161]$.

Genotyping of PON-1 Q192R and L55M polymorphisms was performed in 287 patients with type 2 diabetes and 293 healthy individuals. The frequency of the QR/RR and LM/MM genotypes was significantly higher in patients with type 2 diabetes compared to healthy individuals. In addition, subjects with the $\mathrm{R}$ allele had an increased risk to develop diabetes up to 1.68 times, and individuals with an $\mathrm{M}$ allele had a 2.24-fold risk of developing diabetes. The QR/RR and LM/MM genotypes were associated with higher body mass index (BMI), as well as increased cholesterol, triglycerides, LDL and fasting serum insulin and HOMA-IR [162].

The PON-2 gene polymorphisms $148 \mathrm{~A} / \mathrm{G}$ and S311C have been independently associated with diabetic nephropathy in Type II diabetic patients. The susceptibility to diabetic nephropathy was intensified by the degree of Obesity [163].

A study conducted on 40 Iranian patients with type 2 diabetes, aged 40-65 years, associated the A allele (SNP PON-2-G148A), and C allele (SNP PON-2-C311S) with quantitative insulin sensitivity check index (QUICKI) and homeostasis model assessment for $\beta$-cell function (HOMA-BCF). They observed a relationship between PON-2 and insulin resistance [164]. However, patients sharing the $55 \mathrm{M}$ allele (PON-1 L55M) were prone to having good glycemic control, independent of the presence of PON-2-G148A and PON-2-C311S [165]. Furthermore, the allele T of the polymorphism $(-108 \mathrm{C}>\mathrm{T})$ of PON-1 gene was associated with decreased paraoxonase activity in type 2 diabetic patients; moreover, the frequency of the homozygous TT and heterozygous TC genotype were higher in these patients [166].

\section{Paraoxonase and Neurodegenerative Diseases}

PON-1 and its ability to hydrolyze organophosphates were the first described associations between paraoxonase and the development of neurodegenerative diseases. Lipid peroxidation in the nervous system compromises the myelin sheet, most of times being an irreversible process [167]. Decreased PON-1 activity and decreased PON-2 expression were associated with nervous system oxidative stress and the development of dementias [25].

Alzheimer's disease (AD) is the most common cause of dementia among the elderly over the age of 65 years. As a neurodegenerative disorder, it is characterized by intracellular neurofibrillary tangles and extracellular senile plaques which consist of amyloid $\beta$-peptide $(\mathrm{A} \beta)$. Oxidative stress 
and lipid peroxidation are some of the causes of neurodegenerative disease development [168]. It has been suggested that paraoxonase activity is significantly lower in AD patients. In fact, the presence of PON-2 in the brain confers a protective effect against oxidative stress and neuroinflammation in brain cells, through its ability to eliminate reactive oxygen species (ROS) by exposure to oxidants [33]. Polymorphic changes in several genes such as Cryptochrome Circadian Regulator 1 (CRYL1), ApoE and haptoglobin (HP) have been described in patients with Alzheimer's disease. They were associated with dysregulation of lipid metabolism and cholesterol, as well as with decreased life expectancy [169]. As described above, it is well known that individuals carrying PON-1 R allele have a higher PON serum activity as those carrying the $\mathrm{Q}$ allele. Thus, the involvement of this SNP in patients with AD is not surprising and may be related to its differential activity as an antioxidant enzyme [170]. Another SNP involved in the decrease of PON-1 arylesterase activity in patients with AD is $-108 \mathrm{C}>\mathrm{T}$. in which the lowest enzymatic activities were observed in carriers of the CT and TT genotypes in both sexes [171]. The allele C, of the PON-2 S311C polymorphism, was considered one of the risk factors that can contribute to the development of Alzheimer's disease in the Chinese population [83].

Parkinson's disease (PD) is a disease in which the onset of symptoms occurs in the middle or advanced ages. Clinically, the disease is characterized by resting tremor, stiffness, akinesia and postural disorder. In the disease, death of dopaminergic neurons in the compact zone of the substantia nigra and the appearance of Lewy bodies in the neuronal cytoplasm are observed [172]. However, the etiology of the disease is unknown, although some theories involve prolonged exposure to toxic chemicals, such as organophosphate pesticides (OP) [170]. Membrane lipid peroxidation products have been also associated with the etiology of PD [170]. The involvement of PON-1 in the disease is related to the unbalance in dopamine concentration of acetylcholine (Ach), whose effects are opposed to those of dopamine in the striatum. Exposure to organophosphorus increases the levels of Ach due to blocked cholinesterase (ChE) by non-degraded organophosphates, which in turn induces overproduction $\mathrm{ChE}$ as feedback response [25]. In a study with 246 patients with PD exposed to organophosphates, the L55M polymorphism was described to influence some symptoms of PD progression [173]. 55MM homozygous genotype was associated with a faster progression of motor symptoms, the development of depressive symptoms, and a decrease in the cognitive ability in these patients [173]. This is interesting because the 55MM genotype has been associated with lower PON-1 esterase activity, and several studies have associated lower PON-1 activity with an increased risk of both depression and dementia, and decreased cognition in elderly [174-176].

Another neurodegenerative disease associated with PONs is multiple sclerosis (MS). Multiple sclerosis is a neurological, chronic and autoimmune disease. An oxidative stress promoted by a respiratory burst of invading and resident macrophages and astrocytes triggers a chronic and irreversible inflammatory process, and leads to demyelination, axonal damage and degeneration [177]. During the inflammatory process, a decrease of antioxidants is observed; moreover, PON-1 paraoxonase and arylesterase activities are decreased [178]. Castellazzi et al., [179] have associated the decrease of PON-1 arylesterase activity with the development of dementia in MS, due to redox state dysregulation and increased lipid peroxidation. The SPNs PON-1 L55M and R192Q, however, seem to have no influence on paraoxonase and arylesterase activities [180]. Thus, the reduction of PON-1 esterase activity in multiple sclerosis is probably a characteristic of the disease itself, since the presence of these polymorphisms does not confer a risk factor for the development of MS [181].

Gulf War (GW) syndrome is a disorder that appear to have affected many, but not all, Gulf War veterans, who came in contact with organophosphates compounds. Fatigue, widespread pain, cognitive and memory problems, skin rashes, gastrointestinal and respiratory difficulties were commonly reported. Therefore, not every veteran afflicted by GW illness show identical symptoms. Neurological problems include amyotrophic lateral sclerosis, brain cancer, seizures, neuritis and neuralgia, migraine headaches, multiple sclerosis and Parkinson's disease [182]. As organophosphate pesticides intoxication is implicated in this disease, $\mathrm{PON}-1$ activity and polymorphisms have been 
studied in GW veterans. PON-1 activity was shown to be reduced in patients [131,183]. R allele (heterozygous QR or homozygous RR) was prevalent in patients with neurological symptoms [184].

\section{Paraoxonases and Cancer}

The intense oxidative stress and inflammation process, in the long term, can lead to the carcinogenesis, besides maintaining an ideal environment for the growth of a tumor cell. Cancer cells produce high concentrations of ROS that alter cellular metabolic pathways and mitochondrial and peroxisome functions, and increase cell receptor signaling, inflammatory cytokines and activation of oncogenes [28].

Lower serum PON1 activity has been reported in cancer patients [185]. The signal transduction pathways involved in the modulation of PON1 are PKC, p44/42 and MAPK/ERK, and these pathways are activated by growth factors and other effectors to regulate cell growth and differentiation, apoptosis and angiogenesis [28]. Moreover, in individuals who have been treated for cancer, oxidative stress markers decreased, and the activities of the enzymes antioxants, superoxide dismutase, catalase, paraoxonase-1 higher [186]. The high expression of PON-1 in the liver of older people is important, since this population makes use of large amount of drugs which are metabolized by the liver, and the damage caused by the injury of the hepatic tissue due to the inflammation and oxidative stress can lead to hepatocellular carcinoma [187]. A decrease in PON-1 protein in patients with hepatocellular carcinoma was associated with tumor recurrence, invasiveness, metastasis, as well as with the alterations in cell cycle, DNA replication, gap junctions, and p53 downstream pathways [188]. In patients with colorectal cancer the serum activities of PON1 (paraoxonase and arylesterase) were low in patients with QQ and MM genotypes [189]. In Chinese women the heterozygous and homozygous MM genotypes, and the $\mathrm{M}$ alleles, were associated with an increased risk of breast cancer. In addition, the $\mathrm{M}$ allele was associated with postmenopausal status and increased nodal involvement [190].

In recent years, overexpression of PON2 and PON3 has been observed in cancer cells and it has been proposed that both enzymes may be involved in tumor survival and resistance to stress [25,75]. Due to its antioxidant effect, PON-2 reduces cellular oxidative damage and influences redox signaling, which promotes cellular survival. Elevated PON-2 levels may stabilize tumor cells by enhancing cellular stress resistance, attenuating mitochondrial ROS-mediated apoptosis [76,191]. Wnt/ $\beta$-catenin signaling regulates key cellular functions including proliferation, differentiation, migration, genetic stability, apoptosis, and stem cell renewal, as well as maintenance of cancer stem cells, metastasis and immune control $[192,193]$. In vitro studies have shown that the expression of the PON-2 protein regulates the Wnt/GSK3 $\beta / \beta$-catenin pathway in multiple cell lines (K562, SCC-4, PCI-13); besides, a correlation between PON2 and $\beta$-catenin expression was observed in ex-vivo tumor tissue of oral squamous cell cancer (OSCC). Higher PON-2 expression in OSCC has been associated with tumor relapse, regardless the type of treatment [194]. In addition, a bioinformatic analysis of RNA and DNA sequencing data obtained from tumor samples taken from more than 10.000 patients with 31 different types of cancer indicated that a high level of PON-2 expression correlates with a worst prognosis in patients with multiple types of solid tumors. Moreover, PON-2 located in the nuclear envelope and endoplasmic reticulum, could protect cancer cells against unfavorable environmental conditions and against chemotherapy. Patients with glioblastoma, low grade glioma, liver hepatocellular carcinoma and acute myeloid leukemia, exhibiting higher expression of PON-2, had poor survival when compared with patients with lower PON-2 expression [195].

PON-3 overexpression reduces cytochrome $c$ release and cardiolipin peroxidation, leds to loss in mitochondrial integrity, enhancing cell death resistance in cancers cells by regulating c- MAPK signaling pathway [196]. The mitogen-activated protein kinases (MAPKs) in mammals include c-Jun NH2-terminal kinase (JNK), p38 MAPK, and extracellular signal-regulated kinase (ERK). MAPK signaling pathways contribute to cancer development through the stimulation of cell proliferation, metastasis and drug-resistence [197]. In addition, DNA methylation in PON-3 gene has been associated 
with both, the recurrence and the resistence to 5-fluorouracil during the treatement in colorectal cancer patients [198], as well as prostate cancer [199].

\section{Paraoxanase in Healthy Old People}

Very few studies have been performed on healthy old people. In a study conducted by Cakatay et al., [200] the paraoxonase and arylesterase activities of PON-1 were investigated in healthy subjects: young (22-45 years), middle-aged (46-65 years) and elderly (66-89 years-old). Paraoxonase and arylesterase activities were reduced in middle-aged and elderly when compared to young people. The decreased activities correlated negatively with oxLDL increase; with the increased oxidation of hydrophobic amino acid residues and hydroxy and hydroperoxy derivatives; and with the increased protein carbonylation and protein oxidation products. However, in the Turkish population, the PON-1 activity was no different between young and old people [201]. A meta-analysis consisting of 5962 subjects, 2795 young ( $<65$ years of age) and 3167 old subjects ( $>65$ years of age), described that subjects carrying $R R$ and $Q R$ genotypes ( $R+$ carriers) were favoured in reaching extreme ages, since centenarian and nonagenarian individuals did not have and/or delay the onset of major age-related diseases [202]. In addition, the $\mathrm{R}$ allele was related to the increase in PON-1 activity, and the presence of the $\mathrm{R}$ allele was associated with longevity in healthy Italian octo/nonagenarians/centenarians [203].

Diet and dietary supplements effects on paraoxonases in the elderly are even less studied. In the frailty syndrome, the PON-1 activity showed no difference when frail lean and frail obese healthy individuals were compared [204]. Moreover, no difference in PON-1 activity was observed by dietary supplementation in the elderly with this syndrome [205].

The Mediterranean diet uses foods such as fruit and vegetables, olive oil, and nuts which are rich in nutrients with important antioxidant properties. Several epidemiological studies suggest that a diet rich in natural antioxidants is associated with protective effects against major diseases present in elderly, especially hypertension, insulin resistance, metabolic syndrome, cardiovascular disease [206]. Extra-virgin olive oil, one of the main sources of fat in this diet, has been effective in increasing the activity of PON-1 [207]. This effect was attributed to the low intake of saturated fatty acids, and to the oleic acid enrichment of the phospholipids in HDL, favoring the increase of the hepatic mRNA of PON-1 and its activity [207]. Intake of extra-virgin olive oil by the elderly over a 12-week period was shown to significantly increase plasma PON-1 concentration and the anti-inflammatory activity of HDL and PON-1 [208]. Interestingly, argan oil has been described to improve aging-related disorders, acting in inflammatory states, and is currently emerging as having antiaging properties [209]. It has been observed that the intake of virgin argan oil for three weeks increased PON-1 paraoxonase activity in up to $31.5 \%$ and the PON-1 arylesterase activity up to $45 \%$ [210].

\section{Conclusions and Perspectives}

PON-1, -2 and -3 are potent antioxidant enzymes still relatively unknown in their physiological and pathophysiological aspects in advanced age and age-related diseases. Several studies describe contradictory results. Although they are described to be involved in a number of processes, such as oxidative stress, inflammation-related diseases, atherosclerosis and cardiovascular diseases, cancer, neurodegenerative diseases, infectious diseases, to name a few, robust studies are still required to clarify the clinical relevance of PONs.

Significantly more work is needed to fully elucidate PONs physiological functions as well as understand their modulation and their implications for human health. Studies at the cellular level in a variety of tissues, where PONs could locally confer protection from oxidative damage should be performed. Their distinct substrate specificity and localization point out that they may have different functions in the human body. In addition, future studies will have to increasingly focus on PON2 and PON3. Both these enzymes have shown significant antioxidative potential. PON2 is expressed in nearly all human tissues, and thus may be implicated in many other diseases. 
A deeper understanding of PON functions and modulators would pave the way for clinical and nutritional interventions, including the development of specific pharmacological agents targeting PONs, dietary modifications and healthy lifestyle (consumption of antioxidants, eating "good" fats or exercising).

Longevity is a complex trait that presumably depends on different combinations of genes, environment and chance, all of which vary quantitatively and qualitatively. More and larger studies are needed to generate data with enough statistical power across all the considered PON genotypes. With these data it may be possible to establish the role and effect of PON polymorphisms in healthy aging across the sexes, in all human populations, and in age-related diseases.

Author Contributions: Conceptualization, D.L., C.O.R. and S.P.B.; methodology, D.L., C.O.R. and S.P.B.; writing-original draft preparation, D.L., C.O.R. and S.P.B.; writing-review and editing, D.L., C.O.R. and S.P.B.; supervision, S.P.B.

Funding: This research received no external funding.

Acknowledgments: We are thankful to Conselho Nacional de Desenvolvimento Científico e Tecnológico (CNPq), Brazil, and Coordenação de Aperfeiçoamento de Pessoal de Nível Superior (CAPES), Brazil.

Conflicts of Interest: The authors have no conflicting interests.

\section{References}

1. Salmon, A.B.; Richardson, A.; Pérez, V.I. Update on the oxidative stress theory of aging: Does oxidative stress play a role in aging or healthy aging? Free Radic. Biol. Med. 2010, 48, 642-655. [CrossRef] [PubMed]

2. Jacob, K.D.; Hooten, N.N.; Trzeciak, A.R.; Evans, M.K. Markers of oxidant stress that are clinically relevant in aging and age-related disease. Mech. Ageing Dev. 2013, 134, 139-157. [CrossRef] [PubMed]

3. Liguori, I.; Russo, G.; Curcio, F.; Bulli, G.; Aran, L.; Della-Morte, D.; Gargiulo, G.; Testa, G.; Cacciatore, F.; Bonaduce, D.; et al. Oxidative stress, aging, and diseases. Clin. Interv. Aging 2018, 13, 757-772. [CrossRef] [PubMed]

4. Bydlowski, S.P.; Yunker, R.L.; Subbiah, M.T. Ontogeny of 6-keto-PGF1 $\alpha$ synthesis in rabbit aorta and the effect of premature weaning. Am. J. Physiol. 1987, 252, 14-21.

5. Levy, D.; de Melo, T.C.; Ohira, B.Y.; Fidelis, M.L.; Ruiz, J.L.; Rodrigues, A.; Bydlowski, S.P. Oxysterols selectively promote short-term apoptosis in tumor cell lines. Biochem. Biophys. Res. Commun. 2018, 505, 1043-1049. [CrossRef]

6. Levy, D.; de Melo, T.C.; Ruiz, J.L.; Bydlowski, S.P. Oxysterols and mesenchymal stem cell biology. Chem. Phys. Lipids 2017, 207, 223-230. [CrossRef] [PubMed]

7. Rosa-Fernandes, L.; Maselli, L.M.; Maeda, N.Y.; Palmisano, G.; Bydlowski, S.P. Outside-in, inside-out: Proteomic analysis of endothelial stress mediated by 7-ketocholesterol. Chem. Phys. Lipids 2017, 207, 231-238. [CrossRef]

8. Fernandes, L.R.; Stern, A.C.B.; Cavaglieri, R.C.; Nogueira, F.C.S.; Domont, G.; Palmisano, G.; Bydlowski, S.P. 7-Ketocholesterol overcomes drug resistance in chronic myeloid leukemia cell lines beyond MDR1 mechanism. J. Proteom. 2017, 151, 12-23. [CrossRef] [PubMed]

9. Silva, S.F.; Levy, D.; Ruiz, J.L.M.; de Melo, T.C.; Isaac, C.; Fidelis, M.L.; Rodrigues, A.; Bydlowski, S.P. Oxysterols in adipose tissue-derived mesenchymal stem cell proliferation and death. J. Steroid. Biochem. Mol. Biol. 2017, 169, 164-175. [CrossRef]

10. Ferreira, A.K.; Freitas, V.M.; Levy, D.; Ruiz, J.L.M.; Bydlowski, S.P.; Rici, R.E.G.; Filho, O.M.R.; Chierice, G.O.; Maria, D.A. Anti-angiogenic and anti-metastatic activity of synthetic phosphoethanolamine. PLOS ONE 2013, e57937. [CrossRef] [PubMed]

11. Bydlowski, S.P.; Yunker, R.L.; Rymaszewski, Z.; Subbiah, M.T.R. Coffee extracts inhibit platelet-aggregation in vivo and in vitro. Int. J. Vitam. Nutr. Res. 1987, 57, 217-223.

12. Ruiz, J.L.M.; Fernandes, L.R.; Levy, D.; Bydlowski, S.P. Interrelationship between ATP-binding cassette transporters and oxysterols. Biochem. Pharmacol. 2013, 86, 80-88. [CrossRef] [PubMed]

13. do Amaral, V.F.; Bydlowski, S.P.; Peranovich, T.C.; Navarro, P.A.; Subbiah, M.T.R.; Ferriani, R.A. Lipid peroxidation in the peritoneal fluido $\mathrm{f}$ infertile women with peritoneal endometriosis. Eur. J. Obstet. Gynecol. Reprod. Biol. 2005, 119, 72-75. [CrossRef] [PubMed] 
14. Aviram, M.; Rosenblat, M.; Bisgaier, C.L.; Newton, R.S.; Primo-Parmo, S.L.; La Du, B.N. Paraoxonase inhibits high-density lipoprotein oxidation and preserves its functions. A Possible Peroxidative Role Paraoxonase. J. Clin. Investig. 1998, 101, 1581-1590. [CrossRef]

15. Ng, C.J.; Wadleigh, D.J.; Gangopadhyay, A.; Hama, S.; Grijalva, V.R.; Navab, M.; Fogelman, A.M.; Reddy, S.T. Paraoxonase-2 is a ubiquitously expressed protein with antioxidant properties and is capable of preventing cell-mediated oxidative modification of low density lipoprotein. J. Biol. Chem. 2001, 276, 44444-44449. [CrossRef] [PubMed]

16. Draganov, D.I.; Stetson, P.L.; Watson, C.E.; Billecke, S.S.; La Du, B.N. Rabbit serum paraoxonase 3 (PON3) is a high density lipoprotein-associated lactonase and protects low density lipoprotein against oxidation. J. Biol. Chem. 2000, 275, 33435-33442. [CrossRef]

17. Moya, C.; Máñez, S. Paraoxonases: Metabolic role and pharmacological projection. Naunyn. Schmiedebergs Arch. Pharmacol. 2018, 391, 349-359. [CrossRef] [PubMed]

18. Kanasi, E.; Ayilavarapu, S.; Jones, J. The aging population: Demographics and the biology of aging. Periodontology 2000, 72, 13-18. [CrossRef] [PubMed]

19. Davalli, P.; Mitic, T.; Caporali, A.; Lauriola, A.; D'Arca, D. ROS, Cell Senescence, and Novel Molecular Mechanisms in Aging and Age-Related Diseases. Oxid. Med. Cell. Longev. 2016, 3565127. [CrossRef]

20. Squier, T.C. Oxidative stress and protein aggregation during biological aging. Exp. Gerontol. 2001, 36, 1539-1550. [CrossRef]

21. Ademowo, O.S.; Dias, H.K.I.; Burton, D.G.A.; Griffiths, H.R. Lipid (per) oxidation in mitochondria: An emerging target in the ageing process? Biogerontology 2017, 18, 859-879. [CrossRef] [PubMed]

22. El Assar, M.; Ângulo, J.; Rodríguez-Mañas, L. Oxidative stress and vascular inflammation in aging. Free Radic. Biol. Med. 2013, 65, 380-401. [CrossRef] [PubMed]

23. Sadowska-Bartosz, I.; Bartosz, G. Effect of antioxidants supplementation on aging and longevity. Biomed. Res. Int. 2014, 404680. [CrossRef] [PubMed]

24. Mahrooz, A. Pharmacological Interactions of Paraoxonase 1 (PON1): A HDL-Bound Antiatherogenic Enzyme. Curr. Clin. Pharmacol. 2016, 11, 259-264. [CrossRef] [PubMed]

25. Menini, T.; Gugliucci, A. Paraoxonase 1 in neurological disorders. Redox Rep. 2014, 19, 49-58. [CrossRef] [PubMed]

26. Liu, H.H.; Li, J.J. Aging and dyslipidemia: A review of potential mechanisms. Ageing Res. Rev. 2015, 19, 43-52. [CrossRef] [PubMed]

27. Mau, T.; Yung, R. Adipose tissue inflammation in aging. Exp. Gerontol. 2018, 105, 27-31. [CrossRef] [PubMed]

28. Bacchetti, T.; Ferretti, G.; Sahebkar, A. The role of paraoxonase in cancer. Semin. Cancer Biol. 2017, 1044, 30191-30198. [CrossRef] [PubMed]

29. Primo-Parmo, S.L.; Sorenson, R.C.; Teiber, J.; La Du, B.N. The human serum paraoxonase/arylesterase gene (PON1) is one member of a multigene family. Genomics 1996, 33, 498-507. [CrossRef]

30. Sorenson, R.C.; Primo-Parmo, S.L.; Camper, A.S.; La Du, B.N. The genetic mapping and gene structure of mouse paraoxonase/arylesterase. Genomics 1995, 30, 431-438. [CrossRef]

31. Motti, C.; Dessì, M.; Gnasso, A.; Irace, C.; Indigeno, P.; Angelucci, C.B.; Bernardini, S.; Fucci, G.; Federici, G.; Cortese, C. A multiplex PCR-based DNA assay for the detection of paraoxonase gene cluster polymorphisms. Atherosclerosis 2001, 158, 35-40. [CrossRef]

32. Walker, C.H. The classification of esterases which hydrolyse organophosphates: Recent developments. Chem. Biol. Interact. 1993, 87, 17-24. [CrossRef]

33. Furlong, C.E.; Li, W.F.; Brophy, V.H.; Jarvik, G.P.; Richter, R.J.; Shih, D.M.; Lusis, A.J.; Costa, L.G. The PON1 gene and detoxication. Neurotoxicology 2000, 21, 581-587.

34. Mackness, M.I. 'A'-esterases. Enzymes looking for a role? Biochem. Pharmacol. 1989, 38, 385-390. [CrossRef]

35. Costa, L.G.; Richter, R.J.; Li, W.F.; Cole, T.; Guizzetti, M.; Furlong, C.E. Paraoxonase (PON 1) as a biomarker of susceptibility for organophosphate toxicity. Biomarkers 2003, 8, 1-12. [CrossRef]

36. Draganov, D.I.; Teiber, J.F.; Speelman, A.; Osawa, Y.; Sunahara, R.; La Du, B.N. Human paraoxonases (PON1, PON2, and PON3) are lactonases with overlapping and distinct substrate specificities. J. Lipid Res. 2005, 46, 1239-1247. [CrossRef] [PubMed]

37. Li, X.C.; Wang, C.; Mulchandani, A.; Ge, X. Engineering Soluble Human Paraoxonase 2 for Quorum Quenching. ACS Chem. Biol. 2016, 11, 3122-3131. [CrossRef] 
38. Huang, D.; Wang, Y.; He, Y.; Wang, G.; Wang, W.; Han, X.; Sun, Y.; Lin, L.; Shan, B.; Shen, G.; et al. Paraoxonase 3 is involved in the multi-drug resistance of esophageal cancer. Cancer Cell Int. 2018, 8, 168. [CrossRef]

39. Shunmoogam, N.; Naidoo, P.; Chilton, R. Paraoxonase (PON)-1: A brief overview on genetics, structure, polymorphisms and clinical relevance. Vasc. Health Risk Manag. 2018, 14, 137-143. [CrossRef] [PubMed]

40. Rosenblat, M.; Gaidukov, L.; Khersonsky, O.; Vaya, J.; Oren, R.; Tawfik, D.S.; Aviram, M. The catalytic histidine dyad of high density lipoprotein-associated serum paraoxonase-1 (PON1) is essential for PON1-mediated inhibition of low density lipoprotein oxidation and stimulation of macrophage cholesterol efflux. J. Biol. Chem. 2006, 281, 7657-7665. [CrossRef] [PubMed]

41. Deakin, S.; Moren, X.; James, R.W. Very low density lipoproteins provide a vector for secretion of paraoxonase-1 from cells. Atherosclerosis 2005, 179, 17-25. [CrossRef]

42. Fuhrman, B.; Volkova, N.; Aviram, M. Paraoxonase 1 (PON1) is present in postprandial chylomicrons. Atherosclerosis 2005, 180, 55-61. [CrossRef]

43. Gugliucci, A.; Menini, T. Paraoxonase 1 and HDL maturation. Clin. Chim. Acta. 2015, 439, 5-13. [CrossRef]

44. Diffenderfer, M.R.; Schaefer, E.J. The composition and metabolism of large and small LDL. Curr. Opin. Lipidol. 2014, 25, 221-226. [CrossRef] [PubMed]

45. Mackness, B.; Mackness, M. Anti-inflammatory properties of paraoxonase-1 in atherosclerosis. Adv. Exp. Med. Biol. 2010, 660, 143-151.

46. Kunutsor, S.K.; Bakker, S.J.; James, R.W.; Dullaart, R.P. Serum paraoxonase-1 activity and risk of incident cardiovascular disease: The PREVEND study and meta-analysis of prospective population studies. Atherosclerosis 2016, 245, 143-154. [CrossRef] [PubMed]

47. Selek, S.; Aslan, M.; Horoz, M.; Gur, M.; Erel, O. Oxidative status and serum PON1 activity in beta-thalassemia minor. Clin. Biochem. 2007, 40, 287-291. [CrossRef]

48. Takci, Z.; Bilgili, S.G.; Karadag, A.S.; Kucukoglu, M.E.; Selek, S.; Aslan, M. Decreased serum paraoxonase and arylesterase activities in patients with rosacea. J. Eur. Acad. Dermatol. Venereol. 2015, 29, 367-370. [CrossRef]

49. Yildiz, A.; Gur, M.; Demirbag, R.; Yilmaz, R.; Akyol, S.; Aslan, M.; Erel, O. Paraoxonase and arylesterase activities in untreated dipper and non-dipper hypertensive patients. Clin. Biochem. 2008, 41, 779-784. [PubMed]

50. Camuzcuoglu, H.; Toy, H.; Cakir, H.; Celik, H.; Erel, O. Decreased paraoxonase and arylesterase activities in the pathogenesis of future atherosclerotic heart disease in women with gestational diabetes mellitus. J. Womens Health (Larchmt) 2009, 18, 1435-1439. [CrossRef]

51. Maselli, L.M.; da Cunha, J.; Gutierrez, E.B.; Maranhão, R.C.; Spada, C.; Bydlowski, S.P. Human paraoxonase-1 activity is related to the number of CD4+ T-cells and is restored by antiretroviral therapy in HIV-1-infected individuals. Dis. Markers 2014, 2014, 480201. [CrossRef]

52. Da Cunha, J.; Maselli, L.M.; Treitinger, A.; Monteiro, A.M.; Gidlund, M.; Maranhão, R.C.; Spada, C.; Bydlowski, S.P. Serum levels of IgG antibodies against oxidized LDL and atherogenic indices in HIV-1-infected patients treated with protease inhibitors. Clin. Chem. Lab. Med. 2013, 51, 371-378. [CrossRef]

53. Berrougui, H.; Khalil, A. Age-associated decrease of high-density lipoprotein-mediated reverse cholesterol transport activity. Rejuvenation Res. 2009, 12, 117-126. [CrossRef]

54. Hafez, M.M.; Al-Shabanah, A.O.; Al-Harbi, N.O.; Al-Harbi, M.M.; Al-Rejaie, S.S.; Alsurayea, S.M. Sayed-Ahmed MM. Association between paraoxonases gene expression and oxidative stress in hepatotoxicity induced by $\mathrm{CCl}_{4}$. Oxid. Med. Cell Longev. 2014, 2014, 893212. [CrossRef]

55. Marsillach, J.; Camps, J.; Ferré, N.; Beltran, R.; Rull, A.; Mackness, B.; Mackness, M.; Joven, J. Paraoxonase-1 is related to inflammation, fibrosis and PPAR delta in experimental liver disease. BMC Gastroenterol. 2009, 9, 3. [CrossRef]

56. Stipanuk, M.H. Sulfur amino acid metabolism: Pathways for production and removal of homocysteine and cysteine. Annu. Ver. Nutr. 2004, 24, 539-577. [CrossRef]

57. Finkelstein, J.D. Pathways and regulation of homocysteine metabolism in mammals. Semin. Thromb. Hemost. 2000, 26, 219-225. [CrossRef]

58. Perła-Kaján, J.; Jakubowski, H. Paraoxonase 1 and homocysteine metabolism. Amino Acids 2012, 43, 1405-1417. [CrossRef]

59. Faria-Neto, J.R.; Chagas, A.C.P.; Bydlowski, S.P.; Lemos Neto, S.P.A.; Chamone, D.A.; Ramirez, J.A.F.; da Luz, P.L. Hyperhomocystinemia in patients with coronary artery disease. Braz. J. Med. Biol. Res. 2006, 39, 455-463. [CrossRef] 
60. Genoud, V.; Quintana, P.G.; Gionco, S.; Baldessari, A.; Quintana, I. Structural changes of fibrinogen molecule mediated by the N-homocysteinylation reaction. J. Thromb. Thrombolysis 2018, 45, 66-76. [CrossRef]

61. Eren, E.; Ellidag, H.Y.; Aydin, O.; Yılmaz, N. Homocysteine, Paraoxonase-1 and Vascular Endothelial Dysfunction: Omnibus viis Romam Pervenitur. J. Clin. Diagn. Res. 2014, 8, 1-4. [CrossRef] [PubMed]

62. AnandBabu, K.; Bharathidevi, S.R.; Sripriya, S.; Sem, P.; Prakash, V.J.; Bindu, A.; Viswanathan, N.; Angayarkanni, N. Serum Paraoxonase activity in relation to lipid profile in Age-related Macular Degeneration patients. Exp. Eye Res. 2016, 152, 100-112. [CrossRef]

63. Jamroz-Wiśniewska, A.; Bełtowski, J.; Bartosik-Psujek, H.; Wójcicka, G.; Rejdak, K. Processes of plasma protein N-homocysteinylation in multiple sclerosis. Int. J. Neurosci. 2017, 127, 709-715. [CrossRef] [PubMed]

64. Borowczyk, K.; Shih, D.M.; Jakubowski, H. Metabolism and neurotoxicity of homocysteine thiolactone in mice: Evidence for a protective role of paraoxonase 1. J. Alzheimers Dis. 2012, 30, 225-231. [CrossRef]

65. Humbert, R.; Adler, D.A.; Disteche, C.M.; Hassett, C.; Omiecinski, C.J.; Furlong, C.E. The molecular basis of the human serum paraoxonase activity polymorphism. Nat. Genet. 1993, 3, 73-76. [CrossRef] [PubMed]

66. Adkins, S.; Gan, K.N.; Mody, M.; La Du, B.N. Molecular basis for the polymorphic forms of human serum paraoxonase/arylesterase: Glutamine or arginine at position 191, for the respective A and B allozymes. Am. J. Hum. Genet. 1993, 52, 598-608. [PubMed]

67. Mackness, B.; Mackness, M.I.; Arrol, S.; Turkie, W.; Durrington, P.N. Effect of the molecular polymorphisms of human paraoxonase (PON1) on the rate of hydrolysis of paraoxon. Br. J. Pharmacol. 1997, 122, 265-268. [CrossRef]

68. Cherki, M.; Berrougui, H.; Isabelle, M.; Cloutier, M.; Koumbadinga, G.A.; Khalil, A. Effect of PON1 polymorphism on HDL antioxidant potential is blunted with aging. Exp. Gerontol. 2007, 42, 815-824. [CrossRef]

69. Mochizuki, H.; Scherer, S.W.; Xi, T.; Nickle, D.C.; Majer, M.; Huizenga, J.J.; Tsui, L.C.; Prochazka, M. Human PON2 gene at 7q21.3: Cloning, multiple mRNA forms, and missense polymorphisms in the coding sequence. Gene 1998, 213, 149-157. [CrossRef]

70. Devarajan, A.; Bourquard, N.; Hama, S.; Navab, M.; Grijalva, V.R.; Morvardi, S.; Clarke, C.F.; Vergnes, L.; Reue, K.; Teiber, J.F.; et al. Paraoxonase 2 deficiency alters mitochondrial function and exacerbates the development of atherosclerosis. Antioxid. Redox Signal. 2011, 14, 341-351. [CrossRef]

71. Rom, O.; Aviram, M. Paraoxsonase2 (PON2) and oxidative stress involvement in pomegranate juice protection against cigarette smoke-induced macrophage cholesterol accumulation. Chem. Biol. Interact. 2016, 259, 394-400. [CrossRef]

72. Aviram, M.; Rosenblat, M. Paraoxonases 1, 2, and 3, oxidative stress, and macrophage foam cell formation during atherosclerosis development. Free Radic. Biol. Med. 2004, 37, 1304-1316. [CrossRef]

73. Altenhöfer, S.; Witte, I.; Teiber, J.F.; Wilgenbus, P.; Pautz, A.; Li, H.; Daiber, A.; Witan, H.; Clement, A.M.; Förstermann, U.; et al. One enzyme, two functions: PON2 prevents mitochondrial superoxide formation and apoptosis independent from its lactonase activity. J. Biol. Chem. 2010, 285, 24398-24403. [CrossRef]

74. Garrick, J.M.; Dao, K.; de Laat, R.; Elsworth, J.; Cole, T.B.; Marsillach, J.; Furlong, C.E.; Costa, L.G. Developmental expression of paraoxonase 2. Chem. Biol. Interact. 2016, 259, 168-174. [CrossRef]

75. Furlong, C.E.; Marsillach, J.; Jarvik, G.P.; Costa, L.G. Paraoxonases-1, -2 and -3: What are their functions? Chem. Biol. Interact. 2016, 259, 51-62. [CrossRef]

76. Rajkovic, M.G.; Rumora, L.; Barisic, K. The paraoxonase 1, 2 and 3 in humans. Biochem. Med. (Zagreb) 2011, 21, 122-130. [CrossRef] [PubMed]

77. Giordano, G.; Tait, L.; Furlong, C.E.; Cole, T.B.; Kavanagh, T.J.; Costa, L.G. Gender differences in brain susceptibility to oxidative stress are mediated by levels of paraoxonase-2 expression. Free Radic. Biol. Med. 2013, 58, 98-108. [CrossRef]

78. Précourt, L.P.; Marcil, V.; Ntimbane, T.; Taha, R.; Lavoie, J.C.; Delvin, E.; Seidman, E.G.; Beaulieu, J.F.; Levy, E. Antioxidative properties of paraoxonase 2 in intestinal epithelial cells. Am. J. Physiol. Gastrointest. Liver Physiol. 2012, 303, 623-634. [CrossRef] [PubMed]

79. Levy, E.; Trudel, K.; Bendayan, M.; Seidman, E.; Delvin, E.; Elchebly, M.; Lavoie, J.C.; Precourt, L.P.; Amre, D.; Sinnett, D. Biological role, protein expression, subcellular localization, and oxidative stress response of paraoxonase 2 in the intestine of humans and rats. Am. J. Physiol. Gastrointest. Liver Physiol. 2007, 293, 1252-1261. [CrossRef] 
80. Costa, L.G.; de Laat, R.; Dao, K.; Pellacani, C.; Cole, T.B.; Furlong, C.E. Paraoxonase-2 (PON2) in brain and its potential role in neuroprotection. Neurotoxicology 2014, 43, 3-9. [CrossRef] [PubMed]

81. Shi, S.; Buck, T.M.; Kinlough, C.L.; Marciszyn, A.L.; Hughey, R.P.; Chalfie, M.; Brodsky, J.L.; Kleyman, T.R. Regulation of the epithelial $\mathrm{Na}(+)$ channel by paraoxonase-2. J. Biol. Chem. 2017, 292, 15927-15938. [CrossRef] [PubMed]

82. Reddy, S.T.; Wadleigh, D.J.; Grijalva, V.; Ng, C.; Hama, S.; Gangopadhyay, A.; Shih, D.M.; Lusis, A.J.; Navab, M.; Fogelman, A.M. Human paraoxonase-3 is an HDL-associated enzyme with biological activity similar to paraoxonase-1 protein but is not regulated byoxidized lipids. Arterioscler. Thromb. Vasc. Biol. 2001, 21, 542-547. [CrossRef] [PubMed]

83. Shi, J.; Zhang, S.; Tang, M.; Liu, X.; Li, T.; Han, H.; Wang, Y.; Guo, Y.; Zhao, J.; Li, H.; et al. Possible association between Cys311Ser polymorphism of paraoxonase 2 gene and late-onset Alzheimer's disease in Chinese. Brain Res. Mol. Brain Res. 2004, 120, 201-204. [CrossRef] [PubMed]

84. Rosenblat, M.; Draganov, D.; Watson, C.E.; Bisgaier, C.L.; La Du, B.N.; Aviram, M. Mouse macrophage paraoxonase 2 activity is increased whereas cellular paraoxonase 3 activity is decreased under oxidative stress. Arterioscler. Thromb. Vasc. Biol. 2003, 23, 468-474. [CrossRef] [PubMed]

85. Li, X.; Cao, J.; Wang, J.; Song, H.; Ji, G.; Dong, Q.; Wei, C.; Cao, Y.; Wang, B.; Zhu, B.; et al. PON2 and ATP2B2 gene polymorphisms with noise-induced hearing loss. J. Thorac. Dis. 2016, 8, 430-438. [CrossRef] [PubMed]

86. Sanghera, D.K.; Manzi, S.; Minster, R.L.; Shaw, P.; Kao, A.; Bontempo, F.; Kamboh, M.I. Genetic variation in the paraoxonase-3 (PON3) gene is associated with serum PON1 activity. Ann. Hum. Genet. 2008, 72, 72-81. [CrossRef]

87. Cronin, S.; Greenway, M.J.; Prehn, J.H.; Hardiman, O. Paraoxonase promoter and intronic variants modify risk of sporadic amyotrophic lateral sclerosis. J. Neurol. Neurosurg. Psychiatry 2007, 78, 984-986. [CrossRef]

88. Nozue, T.; Yamamoto, S.; Tohyama, S.; Fukui, K.; Umezawa, S.; Onishi, Y.; Kunishima, T.; Hibi, K.; Terashima, M.; Michishita, I. A predictor of atheroma progression in patients achieving very low levels of low-density lipoprotein cholesterol. Am. J. Cardiovasc. Dis. 2013, 3, 255-263.

89. Akbas, H.S.; Basyigit, S.; Suleymanlar, I.; Kemaloglu, D.; Koc, S.; Davran, F.; Demir, I.; Suleymanlar, G. The assessment of carotid intima media thickness and serumparaoxonase-1 activity in Helicobacter pylori positive subjects. Lipids Health Dis. 2010, 30, 92. [CrossRef]

90. Mete, R.; Oran, M.; Alpsoy, S.; Gunes, H.; Tulubas, F.; Turan, C.; Topcu, B.; Aydin, M.; Yildirim, O. Carotid intima-media thickness and serum paraoxonase-1 activity inpatients with Helicobacter pylori. Eur. Rev. Med. Pharmacol. Sci. 2013, 17, 2884-2889.

91. Aragonès, G.; García-Heredia, A.; Guardiola, M.; Rull, A.; Beltrán-Debón, R.; Marsillach, J.; Alonso-Villaverde, C.; Mackness, B.; Mackness, M.; Pedro-Botet, J.; et al. Serum paraoxonase-3 concentration in HIV-infected patients. Evid. A Prot. Role Against Oxid. J. Lipid Res. 2012, 53, 168-174.

92. Feleciano, D.R.; Kirstein, J. Collapse of redox homeostasis during aging and stress. Mol. Cell. Oncol. 2015, 3, e1091060. [CrossRef]

93. Rongo, C. Better to burn out than it is to rust: Coordinating cellular redox states during aging and stress. EMBO J. 2015, 34, 2310-2311. [CrossRef] [PubMed]

94. Ogłodek, E.A. The role of PON-1, GR, IL-18, and OxLDL in depression with and without posttraumatic stress disorder. Pharmacol. Rep. 2017, 69, 837-845. [CrossRef]

95. Johnston-Carey, H.K.; Pomatto, L.C.; Davies, K.J. The Immunoproteasome in oxidative stress, aging, and disease. Crit. Ver. Biochem. Mol. Biol. 2015, 51, 268-281. [CrossRef] [PubMed]

96. Pradas, I.; Jové, M.; Huynh, K.; Puig, J.; Ingles, M.; Borras, C.; Viña, J.; Meikle, P.J.; Pamplona, R. Exceptional human longevity is associated with a specific plasma phenotype of ether lipids. Redox Biol. 2019, 21, 101-127. [CrossRef] [PubMed]

97. Wei, M.; Brandhorst, S.; Shelehchi, M.; Mirzaei, H.; Cheng, C.W.; Budniak, J.; Groshen, S.; Mack, W.J.; Guen, E.; Di Biase, S.; et al. Fasting-mimicking diet and markers/risk factors for aging, diabetes, cancer, and cardiovascular disease. Sci. Transl. Med. 2017, 9, e8700. [CrossRef] [PubMed]

98. Lee, Y.S.; Park, C.O.; Noh, J.Y.; Jin, S.; Lee, N.R.; Noh, S.; Lee, J.H.; Lee, K.H. Knockdown of paraoxonase 1 expression influences the ageing of human dermal microvascular endothelial cells. Exp. Dermatol. 2012, 21, 682-687. [CrossRef] [PubMed]

99. Christiansen, L.; Bathum, L.; Frederiksen, H.; Christensen, K. Paraoxonase 1 polymorphisms and survival. Eur. J. Hum. Genet. 2004, 12, 843-847. [CrossRef] 
100. Caliebe, A.; Kleindorp, R.; Blanché, H.; Christiansen, L.; Puca, A.A.; Rea, I.M.; Slagboom, E.; Flachsbart, F.; Christensen, K.; Rimbach, G.; et al. No or only population-specific effect of PON1 on human longevity: A comprehensive meta-analysis. Ageing Res. Rev. 2010, 9, 238-244. [CrossRef]

101. Li, Y.; Liang, G.; Shi, L.; Liang, X.; Long, B.; Qin, J.; Zhang, Z. Paraoxonase-1 (PON1) rs662 Polymorphism and Its Association with Serum Lipid Levels and Longevity in the Bama Zhuang Population. Med. Sci. Monit. 2016, 22, 5154-5162. [CrossRef]

102. Tanhapour, M.; Miri, A.; Vaisi-Raygani, A.; Bahrehmand, F.; Kiani, A.; Rahimi, Z.; Pourmotabbed, T.; Shakiba, E. Synergism between apolipoprotein E $\varepsilon 4$ allele and paraoxonase (PON1) 55-M allele is associated with risk of systemic lúpus erythematosus. Clin. Rheumatol. 2018, 37, 971-977. [CrossRef]

103. Mehdi, M.M.; Rizvi, S.I. Human plasma paraoxonase 1 (PON1) arylesterase activity during aging: Correlation with susceptibility of LDL oxidation. Arch. Med. Res. 2012, 43, 438-443. [CrossRef]

104. Kubben, N.; Misteli, T. Shared molecular and cellular mechanisms of premature ageing and ageing-associated diseases. Nat. Rev. Mol. Cell Biol. 2017, 18, 595-609. [CrossRef]

105. Jęśko, H.; Wencel, P.; Strosznajder, R.P.; Strosznajder, J.B. Sirtuins and Their Roles in Brain Aging and Neurodegenerative Disorders. Neurochem. Res. 2017, 42, 876-890. [CrossRef]

106. van de Ven, R.A.H.; Santos, D.; Haigis, M.C. Mitochondrial Sirtuins and Molecular Mechanisms of Aging. Trends Mol. Med. 2017, 23, 320-331. [CrossRef]

107. Wang, Y.; He, J.; Liao, M.; Hu, M.; Li, W.; Ouyang, H.; Wang, X.; Ye, T.; Zhang, Y.; Ouyang, L. An overview of Sirtuins as potential therapeutic target: Structure, function and modulators. Eur. J. Med. Chem. 2019, 161, 48-77. [CrossRef]

108. Cazzaniga, A.; Locatelli, L.; Castiglioni, S.; Maier, J.A.M. The dynamic adaptation of primary human endothelial cells to simulated microgravity. FASEB J. 2019, fj201801586RR. [CrossRef]

109. Breitenstein, A.; Wyss, C.A.; Spescha, R.D.; Franzeck, F.C.; Hof, D.; Riwanto, M.; Hasun, M.; Akhmedov, A.; von Eckardstein, A.; Maier, W.; et al. Peripheral blood monocyte Sirt1 expression is reduced in patients with coronary artery disease. PLoS ONE 2013, 8, e53106. [CrossRef]

110. Kilic, U.; Gok, O.; Erenberk, U.; Dundaroz, M.R.; Torun, E.; Kucukardali, I.; Elibol-Can, B.; Uysal, O.; Dundar, T. A Remarkable Age-Related Increase in SIRT1 Protein Expression against Oxidative Stress in Elderly: SIRT1 Gene Variants and Longevity in Human. PLoS ONE 2015, 10, e0117954. [CrossRef]

111. Rognoni, A.; Cavallino, C.; Veia, A.; Bacchini, S.; Rosso, R.; Facchini, M.; Secco, G.G.; Lupi, A.; Nardi, F.; Rametta, F.; et al. Pathophysiology of Atherosclerotic Plaque Development. Cardiovasc. Hematol. Agents Med. Chem. 2015, 13, 10-13. [CrossRef]

112. Wang, J.C.; Bennett, M. Aging and atherosclerosis: Mechanisms, functional consequences, and potential therapeutics for cellular senescence. Circ. Res. 2012, 111, 245-259. [CrossRef]

113. Camaré, C.; Pucelle, M.; Nègre-Salvayre, A.; Salvayre, R. Angiogenesis in the atherosclerotic plaque. Redox Biol. 2017, 12, 18-34. [CrossRef]

114. Steinberg, D. The LDL modification hypothesis of atherogenesis: An update. J. Lipid Res. 2009, 50, $376-381$. [CrossRef] [PubMed]

115. Childs, B.G.; Baker, D.J.; Wijshake, T.; Conover, C.A.; Campisi, J.; van Deursen, J.M. Senescent intimal foam cells are deleterious at all stages of atherosclerosis. Science 2016, 354, 472-477. [CrossRef]

116. Balder, J.W.; Staels, B.; Kuivenhoven, J.A. Pharmacological interventions in human HDL metabolism. Curr. Opin. Lipidol. 2013, 24, 500-509. [CrossRef]

117. Alique, M.; Luna, C.; Carracedo, J.; Ramírez, R. LDL biochemical modifications: A link between atherosclerosis and aging. Food Nutr. Res. 2015, 59, e29240. [CrossRef] [PubMed]

118. März, W.; Kleber, M.E.; Scharnagl, H.; Speer, T.; Zewinger, S.; Ritsch, A.; Parhofer, K.G.; von Eckardstein, A.; Landmesser, U.; Laufs, U. HDL cholesterol: Reappraisal of its clinical relevance. Clin. Res. Cardiol. 2017, 106, 663-675. [PubMed]

119. Estrada-Luna, D.; Ortiz-Rodriguez, M.A.; Medina-Briseño, L.; Carreón-Torres, E.; Izquierdo-Veja, J.Á.; Sharma, A.; Cancino-Díaz, J.C.; Pérez-Méndez, O.; Belefant-Miller, H.; Betanzos-Cabrera, G. Current Therapies Focused on High-Density Lipoproteins Associated with Cardiovascular Disease. Molecules 2018, 23, 2730. [CrossRef]

120. Pirillo, A.; Catapano, A.L. Pitavastatin and HDL: Effects on plasma levels and function(s). Atheroscler. Suppl. 2017, 2, 1-9. [CrossRef] 
121. Mackness, M.I.; Durrington, P.N. High density lipoprotein, its enzymes and its potential to influence lipid peroxidation. Atherosclerosis 1995, 115, 243-253. [CrossRef]

122. Ikhlef, S.; Berrougui, H.; Simo, O.K.; Zerif, E.; Khalil, A. Human paraoxonase 1 overexpression in mice stimulates HDL cholesterol efflux and reverse cholesterol transport. PLoS ONE 2017, 12, e0173385. [CrossRef]

123. Ng, C.J.; Hama, S.Y.; Bourquard, N.; Navab, M.; Reddy, S.T. Adenovirus mediated expression of human paraoxonase 2 protects against the development of atherosclerosis in apolipoprotein E-deficient mice. Mol. Genet. Metab. 2006, 89, 368-3673. [CrossRef]

124. Ng, C.J.; Bourquard, N.; Hama, S.Y.; Shih, D.; Grijalva, V.R.; Navab, M.; Fogelman, A.M.; Reddy, S.T. Adenovirus-mediated expression of human paraoxonase 3 protects against the progression of atherosclerosis in apolipoprotein E-deficient mice. Arterioscler. Thromb. Vasc. Biol. 2007, 27, 1368-1374. [CrossRef]

125. Mackness, B.; Mackness, M. The antioxidant properties of high-density lipoproteins in atherosclerosis. Panminerva Med. 2012, 54, 83-90. [PubMed]

126. Mackness, M.; Mackness, B. Current aspects of paraoxonase-1 research. In The HDL Handbook-Biological Functions and Clinical Implications, 2nd ed.; Komoda, T., Ed.; Academic Press: London, UK, 2014; pp. $273-291$.

127. Mackness, M.I.; Arrol, S.; Durrington, P.N. Paraoxonase prevents accumulation of lipoperoxides in low-density lipoprotein. FEBS Lett. 1991, 286, 152-154. [CrossRef]

128. Mackness, M.I.; Abbott, C.A.; Arrol, S.; Durrington, P.N. The role of high density lipoprotein and lipid-soluble antioxidant vitamins in inhibiting low-density lipoprotein oxidation. Biochem. J. 1993, 294, 829-835. [CrossRef] [PubMed]

129. Mackness, M.I.; Arrol, S.; Abbott, C.A.; Durrington, P.N. Protection of low-density lipoprotein against oxidative modification by high-density lipoprotein associated paraoxonase. Atherosclerosis 1993, 104, 129-135. [CrossRef]

130. Mackness, B.; Hunt, R.; Durrington, P.N.; Mackness, M.I. Increased immune localization of paraoxonase, clusterin and apolipoprotein AI in the human artery wall with progression of atherosclerosis. Arterioscler. Thromb. Vasc. Biol. 1997, 17, 1233-1238. [CrossRef] [PubMed]

131. Mackness, B.; Durrington, P.N.; Mackness, M.I. Human serum paraoxonase. Gen. Pharmacol. 1998, 31, 329-336. [CrossRef]

132. Mackness, B.; Mackness, M.I.; Arrol, S.; Turkie, W.; Durrington, P.N. Effect of the human serum paraoxonase 55 and 192 genetic polymorphisms on the protection by high density lipoprotein against low density lipoprotein oxidative modification. FEBS Lett. 1998, 423, 57-60. [CrossRef]

133. Mackness, B.; Davies, G.K.; Turkie, W.; Lee, E.; Roberts, D.H.; Hill, E.; Roberts, C.; Durrington, P.N.; Mackness, M.I. Paraoxonase Status Coron. Heart Disease. Are Act. Conc. More Important Than Genotype? Arterioscler. Thromb. Vasc. Biol. 2001, 21, 1451-1457. [CrossRef] [PubMed]

134. Mackness, B.; Durrington, P.; McElduff, P.; Yarnell, J.; Azam, N.; Watt, M.; Mackness, M. Low paraoxonase activity predicts coronary events in the Caerphilly Prospective Study. Circulation 2003, 107, 2775-2779. [CrossRef]

135. Mackness, B.; Durrington, P.; Povey, A.; Thomson, S.; Dippnall, M.; Mackness, M.; Smith, T.; Cherry, N. Paraoxonase and susceptibility to organophosphorus poisoning in farmers dipping sheep. Pharmacogenetics 2003, 13, 81-88. [CrossRef]

136. Mackness, B.; Hine, D.; Liu, Y.; Mastorikou, M.; Mackness, M. Paraoxonase 1 inhibits oxidised LDL-induced MCP-1 production by endothelial cells. Biochem. Biophys. Res. Commun. 2004, 318, 680-683. [CrossRef]

137. Mackness, B.; Quarck, R.; Verreth, W.; Mackness, M.; Holvoet, P. Human paraoxonase-1 overexpression inhibits atherosclerosis in a mouse model of metabolic syndrome. Arterioscler. Thromb. Vasc. 2006, 26, 1545-1550. [CrossRef]

138. White, C.R.; Anantharamaiah, G.M. Cholesterol Reduction and Macrophage Function: Role of Paraoxonases. Curr. Opin. Lipidol 2017, 28, 397-402. [CrossRef] [PubMed]

139. Liu, Y.; Mackness, B.; Mackness, M. Comparison of the ability of paraoxonases 1 and 3 to attenuate the in vitro oxidation of low-density lipoprotein and reduce macrophage oxidative stress. Free Radic. Biol. Med. 2008, 45, 743-748. [CrossRef] [PubMed]

140. Soran, H.; Schofield, J.D.; Durrington, P.N. Antioxidant properties of HDL. Front. Pharmacol. 2015, 6, 1-6. [CrossRef] [PubMed] 
141. Bhattacharyya, T.; Nicholls, S.J.; Topol, E.J.; Zhang, R.; Yang, X.; Schmitt, D.S.; Fu, X.; Shao, M.; Brennan, D.M.; Ellis, S.G.; et al. Relationship of paraoxonase1 (PON1) gene polymorphisms and functional activity with systemic oxidative stress and cardiovascular risk. JAMA 2008, 299, 1265-1276. [CrossRef]

142. Karlsson, H.; Kontush, A.; James, R.W. Functionality of HDL: Antioxidation and etoxifying effects. Handb. Exp. Pharmacol. 2015, 224, 207-228. [PubMed]

143. Mackness, M.; Mackness, B. Human paraoxonase-1 (PON1): Gene structure and expression, promiscuous activities and multiple physiological roles. Gene 2015, 567, 12-21. [CrossRef]

144. Shih, D.M.; Yu, J.M.; Vergnes, L.; Dali-Youcef, N.; Champion, M.D.; Devarajan, A.; Zhang, P.; Castellani, L.W.; Brindley, D.N.; Jamey, C.; et al. PON3 knockout mice are susceptible to obesity, gallstone formation, andatherosclerosis. FASEB J. 2015, 29, 1185-1197. [CrossRef] [PubMed]

145. Lesnefsky, E.J.; Hoppel, C.L. Ischemia-reperfusion injury in the aged heart: Role of mitochondria. Arch. Biochem. Biophys. 2003, 420, 287-297. [CrossRef]

146. Eghbali, M.; Reddy, S.T. Paraoxonase 2 protects against acute myocardial ischemia-reperfusion injury by modulating mitochondrial function and oxidative stress via the PI3K/Akt/GSK-3 $\beta$ RISK pathway. J. Mol. Cell. Cardiol. 2019, 154-164.

147. Ansari, S.A.; Pendurthi, U.R.; Rao, L.V.M. The lipid peroxidation product4-hydroxy-2-nonenal induces tissue factor decryption via ROS generation and the thioredoxin system. Blood Adv. 2017, 1, 2399-2413. [CrossRef] [PubMed]

148. Ebert, J.; Wilgenbus, P.; Teiber, J.F.; Jurk, K.; Schwierczek, K.; Döhrmann, M.; Xia, N.; Li, H.; Spiecker, L.; Ruf, W.; et al. Paraoxonase-2 regulates coagulation activation through endothelial tissue factor. Blood 2018, 131, 161-2172. [CrossRef]

149. Deng, Z.; Xiang, H.; Gao, W. Significant association between paraoxonase 1 rs662 polymorphism and coronary heart disease: A meta-analysis in the Chinese population. Herz 2018, 1, 1-9. [CrossRef]

150. Chi, D.S.; Ling, W.H.; Ma, J.; Xia, M.; Hou, M.J.; Wang, Q.; Zhu, H.L.; Tang, Z.H.; Yu, X.P. Study of the association between paraoxonase1 $55 \mathrm{Met} / \mathrm{Leu}$, paraoxonase2 $148 \mathrm{Ala} / \mathrm{Gly}$ and manganese superoxide dismutase (MnSOD) 9 Ala/Val genetic polymorphisms and coronary heart disease. Zhonghua Liu Xing Bing Xue Za Zhi 2006, 27, 808-813.

151. Marchegiani, F.; Spazzafumo, L.; Provinciali, M.; Cardelli, M.; Olivieri, F.; Franceschi, C.; Lattanzio, F.; Antonicelli, R. Paraoxonase2 C311S polymorphism and low levels of HDL contribute to a higher mortality risk after acute myocardial infarction in elderly patients. Mol. Genet. Metab. 2009, 98, 314-318. [CrossRef]

152. Jalilian, A.; Javadi, E.; Akrami, M.; Fakhrzadeh, H.; Heshmat, R.; Rahmani, M.; Bandarian, F. Association of cys 311 ser polymorphism of paraoxonase-2 gene with the risk of coronary artery disease. Arch. Iran Med. 2008, 11, 544-549.

153. Rains, J.L.; Jain, S.K. Oxidative stress, insulin signaling, and diabetes. Free Radic Biol Med. 2011, 50, 567-575. [CrossRef] [PubMed]

154. Koren-Gluzer, M.; Aviram, M.; Hayek, T. Paraoxonase1 (PON1) reduces insulin resistance in mice fed a high-fat diet, and promotes GLUT4 overexpression in myocytes, via the IRS-1/Akt pathway. Atherosclerosis 2013, 229, 71-78. [CrossRef]

155. Amitai, G.; Gaidukov, L.; Adani, R.; Yishay, S.; Yacov, G.; Kushnir, M.; Teitlboim, S.; Lindenbaum, M.; Bel, P.; Khersonsky, O; i et al. Enhanced stereos elective hydrolysis of toxic organophosphates by directly evolved variants of mammalian serum paraoxonase. FEBS J. 2006, 273, 1906-1919. [CrossRef] [PubMed]

156. Lee, S.J.; Kang, H.K.; Choi, Y.J.; Eum, W.S.; Park, J.; Choi, S.Y.; Kwon, H.Y. PEP-1-paraoxonase 1 fusion protein prevents cytokine-induced cell destruction and impaired insulin secretion in rat insulinoma cells. BMB Rep. 2018, 51, 538-543. [CrossRef]

157. Shih, D.M.; Meng, Y.; Sallam, T.; Vergnes, L.; Shu, M.L.; Reue, K.; Tontonoz, P.; Fogelman, A.M.; Lusis, A.J.; Reddy, S.T. PON2 Deficiency Leads to Increased Susceptibility to Diet-Induced Obesity. Antioxidants 2019, 8, 19. [CrossRef] [PubMed]

158. Golzari, M.H.; Javanbakht, M.H.; Ghaedi, E.; Mohammadi, H.; Djalali, M. Effect of Eicosapentaenoic Acid Supplementation on Paraoxonase 2 Gene Expression in Patients with Type 2 Diabetes Mellitus: A Randomized Double-blind Clinical Trial. Clin. Nutr. Res. 2019, 8, 17-27. [CrossRef] [PubMed]

159. Dye, L.; Boyle, N.B.; Champ, C.; Lawton, C. The relationship between obesity and cognitive health and decline. Proc. Nutr. Soc. 2017, 76, 443-454. [CrossRef] 
160. Alaminos-Castillo, M.Á.; Ho-Plagaro, A.; García-Serrano, S.; Santiago-Fernandez, C.; Rodríguez-Pacheco, F.; Garrido-Sanchez, L.; Rodriguez, C.; Valdes, S.; Gonzalo, M.; Moreno-Ruiz, F.J.; et al. Increased PON lactonase activity in morbidly obese patients is associated with impaired lipid profile. Int. J. Clin. Pract. 2019, e13315. [CrossRef]

161. Fülöp, P.; Harangi, M.; Seres, I.; Paragh, G. Paraoxonase-1 and adipokines: Potential links between obesity and atherosclerosis. Chem. Biol. Interact. 2016, 259, 388-393. [CrossRef]

162. GomathI, P.; Iyer, A.C.; Murugan, O.S.; Sasikumar, S.; Raj, N.B.A.J.; Ganesan, D.; Nallaperumal, S.; Murugan, M.; Selvam, G.S. Association of paraoxonase-1 gene polymorphisms with insulin resistance in South Indian population. Gene 2018, 650, 55-59. [CrossRef]

163. Pinizzotto, M.; Castillo, E.; Fiaux, M.; Temler, E.; Gaillard, R.C.; Ruiz, J. Paraoxonase2 polymorphisms are associated with nephropathy in Type II diabetes. Diabetologia 2001, 44, 104-107. [CrossRef] [PubMed]

164. Qujeq, D.; Mahrooz, A.; Alizadeh, A.; Boorank, R. Paraoxonase-2 variants potentially influence insulin resistance, beta-cell function, and their interrelationships with alanine aminotransferase in type 2 diabetes. J. Res. Med. Sci. 2018, 23, 107. [PubMed]

165. Mahrooz, A.; Hashemi-Soteh, M.B.; Heydari, M.; Boorank, R.; Ramazani, F.; Mahmoudi, A.; Kianmehr, A.; Alizadeh, A. Paraoxonase 1 (PON1)-L55M among common variants in the coding region of the paraoxonase gene family may contribute to the glycemic control in type 2 diabetes. Clin. Chim. Acta 2018, 484, 40-46. [CrossRef] [PubMed]

166. Shakeri, R.; Khajeniazi, S.; Marjani, A. Association between promoter polymorphism $(-108 \mathrm{C}>\mathrm{T})$ of paraoxonase1 gene and it's paraoxonase activity in patients with Type2 diabetes in northern Iran. Clin. Chim. Acta 2017, 474, 34-37. [CrossRef]

167. Reed, T.T. Lipid peroxidation and neurodegenerative disease. Free Radic. Biol. Med. 2011, 51, $1302-1319$. [CrossRef]

168. Arimon, M.; Takeda, S.; Post, K.L.; Svirsky, S.; Hyman, B.T.; Berezovska, O. Oxidative stress and lipid peroxidation are upstream of amyloid pathology. Neurobiol. Dis. 2015, 84, 109-119. [CrossRef]

169. Tindale, L.C.; Leach, S.; Spinelli, J.J.; Brooks-Wilson, A.R. Lipid and Alzheimer's disease genes associated with healthy aging and longevity in healthy oldest-old. Oncotarget 2017, 8, 20612-20621. [CrossRef]

170. Goswami, B.; Tayal, D.; Gupta, N.; Mallika, V. Paraoxonase: A multifaceted biomolecule. Clin. Chim. Acta 2009, 410, 1-12. [CrossRef]

171. Saeidi, M.; Shakeri, R.; Marjani, A.; Khajeniazi, S. Alzheimer's Disease and Paraoxonase 1 (PON1) Gene Polymorphisms. Open Biochem. J. 2017, 11, 47-55. [CrossRef]

172. Kalia, L.V.; Lang, A.E. Parkinson's disease. Lancet 2015, 386, 896-912. [CrossRef]

173. Paul, K.C.; Sinsheimer, J.S.; Cockburn, M.; Bronstein, J.M.; Bordelon, Y.; Ritz, B. Organophosphate pesticides and PON1 L55M in Parkinson's disease progression. Environ. Int. 2017, 107, 75-81. [CrossRef] [PubMed]

174. Barim, A.O.; Aydin, S.; Colak, R.; Dag, E.; Deniz, O.; Sahin, I. Ghrelin, paraoxonase and arylesterase levels in depressive patients before and after citalopram treatment. Clin. Biochem. 2009, 42, 1076-1081. [CrossRef] [PubMed]

175. Bednarska-Makaruk, M.; Rodo, M.; Szirkowiec, W.; Mossakowska, M.; Puzianowska-Kuźnicka, M.; Skalska, A.; Zdrojewski, T.; Ryglewicz, D.; Wehr, H. Paraoxonase 1 activity and level of antibodies directed against oxidized low density lipoproteins in a group of elderly population in Poland-PolSenior study. Arch. Gerontol. Geriatr. 2015, 60, 153-161. [CrossRef]

176. Bednarska-Makaruk, M.; Graban, A.; Wiśniewska, A.; Łojkowska, W.; Bochyńska, A.; Gugała-Iwaniuk, M.; Sławińska, K.; Ługowska, A.; Ryglewicz, D.; Wehr, H. Association of adiponectin, leptin and resistin with inflammatory markers and obesity in dementia. Biogerontology 2017, 18, 561-580. [CrossRef]

177. Correale, J.; Gaitán, M.I.; Ysrraelit, M.C.; Fiol, M.P. Progressive multiple sclerosis: From pathogenic mechanisms to treatment. Brain 2017, 140, 527-546. [CrossRef]

178. Kirbas, A.; Kirbas, S.; Anlar, O.; Efe, H.; Yilmaz, A. Serum paraoxonase and arylesterase activity and oxidative status in patients with multiple sclerosis. J. Clin. Neurosci. 2013, 20, 1106-1109. [CrossRef] [PubMed]

179. Castellazzi, M.; Trentini, A.; Romani, A.; Valacchi, G.; Bellini, T.; Bonaccorsi, G.; Fainardi, E.; Cavicchio, C.; Passaro, A.; Zuliani, G.; et al. Decreased arylesterase activity of paraoxonase-1 (PON-1) might be a common denominator of neuroinflammatory and neurodegenerative diseases. Int. J. Biochem. Cell Biol. 2016, 81, 356-363. [CrossRef] 
180. Moghtaderi, A.; Hashemi, M.; Sharafaddinzadeh, N.; Dabiri, S.; Moazeni-Roodi, A.; Ramroodi, N.; Zolfaghari, M. Lack of association between paraoxonase 1 Q192R polymorphism and multiple sclerosis in relapse phase: A case-control study. Clin. Biochem. 2011, 44, 795-798. [CrossRef]

181. Martínez, C.; García-Martín, E.; Benito-León, J.; Calleja, P.; Díaz-Sánchez, M.; Pisa, D.; Alonso-Navarro, H.; Ayuso-Peralta, L.; Torrecilla, D.; Agúndez, J.Á.; et al. Paraoxonase 1 polymorphisms are not related with the risk for multiple sclerosis. Neuromol. Med. 2010, 12, 217-223. [CrossRef]

182. White, R.F.; Steele, L.; O'Callaghan, J.P.; Sullivan, K.; Binns, J.H.; Golomb, B.A.; Bloom, F.E.; Bunker, J.Á.; Crawford, F.; Graves, J.C.; et al. Recent research on Gulf War illness and other health problems in veterans of the 1991 Gulf War: Effects of toxicant exposures during deployment. Cortex 2016, 74, 449-475. [CrossRef]

183. Hotopf, M.; Mackness, M.I.; Nikolaou, V.; Collier, D.A.; Curtis, C.; David, A.; Durrington, P.; Hull, L.; Ismail, K.; Peakman, M.; et al. Paraoxonase in Persian Gulf War veterans. J. Occup. Environ. Med. 2003, 45, 668-675. [CrossRef] [PubMed]

184. Haley, R.W.; Billecke, S.; La Du, B.N. Association of low PON1 type Q (type A) arylesterase activity with neurologic symptom complexes in Gulf War veterans. Toxicol. Appl. Pharmacol. 1999, 157, 227-233. [CrossRef] [PubMed]

185. Arenas, M.; Rodríguez, E.; Sahebkar, A.; Sabater, S.; Rizo, D.; Pallisé, O.; Hernández, M.; Riu, F.; Camps, J.; Joven, J. Paraoxonase-1 activity in patients with cancer: A systematic review and meta-analysis. Crit. Rev. Oncol. Hematol. 2018, 127, 6-14. [CrossRef] [PubMed]

186. Bozan, N.; Demir, H.; Gürsoy, T.; Özkan, H.; Düzenli, U.; Sarıkaya, E.; Turan, M.; Kiroglu, A.F.; Çankaya, H. Alterations in oxidative stress markers in laryngeal carcinoma patients. J. Chin. Med. Assoc. 2018, 81, 811-815. [CrossRef] [PubMed]

187. Tajiri, K.; Shimizu, Y. Liver physiology and liver diseases in the elderly. World J. Gastroenterol. 2013, 19, 8459-8467. [CrossRef] [PubMed]

188. Yu, Z.; Ou, Q.; Chen, F.; Bi, J.; Li, W.; Ma, J.; Wang, R.; Huang, X. Evaluation of the prognostic value of paraoxonase 1 in the recurrence and metastasis of hepatocellular carcinoma and establishment of a liver-specific predictive model of survival. J. Transl. Med. 2018, 16, 327. [CrossRef] [PubMed]

189. Ahmed, N.S.; Shafik, N.M.; Elraheem, O.A.; Abou-Elnoeman, S.E. Association of paraoxonase-1(Q192R and L55M) gene polymorphisms and activity with colorectal cancer and effect of surgical intervention. Asian Pac. J. Cancer Prev. 2015, 16, 803-809. [CrossRef] [PubMed]

190. Wu, J.; Fang, M.; Zhou, X.; Zhu, B.; Yang, Z. Paraoxonase 1 gene polymorphisms are associated with an increased risk of breast cancer in a population of Chinese women. Oncotarget 2017, 8, 25362-25371. [CrossRef]

191. Krüger, M.; Pabst, A.M.; Al-Nawas, B.; Horke, S.; Moergel, M. Paraoxonase-2 (PON2) protects oral squamous cell cancer cells against irradiation-induced apoptosis. J. Cancer Res. Clin. Oncol. 2015, 141, 1757-1766. [CrossRef] [PubMed]

192. Pai, S.G.; Carneiro, B.A.; Mota, J.M.; Costa, R.; Leite, C.A.; Barroso-Sousa, R.; Kaplan, J.B.; Chae, Y.K.; Giles, F.J. Wnt/beta-catenin pathway: Modulating anticancer immune response. J. Hematol. Oncol. 2017, 10, 101. [CrossRef]

193. Zhan, T.; Rindtorff, N.; Boutros, M. Wnt signaling in cancer. Oncogene 2017, 36, 1461-1473. [CrossRef]

194. Krüger, M.; Amort, J.; Wilgenbus, P.; Helmstädter, J.P.; Grechowa, I.; Ebert, J.; Tenzer, S.; Moergel, M.; Witte, I.; Horke, S. The anti-apoptotic PON2 protein is Wnt/ $\beta$-catenin-regulated and correlates with radiotherapy resistance in OSCC patients. Oncotarget 2016, 7, 51082-51095. [CrossRef]

195. Shakhparonov, M.I.; Antipova, N.V.; Shender, V.O.; Shnaider, P.V.; Arapidi, G.P.; Pestov, N.B.; Pavlyukov, M.S. Expression and Intracellular Localization of Paraoxonase 2 in Different Types of Malignancies. Acta Nat. 2018, 10, 92-99. [CrossRef]

196. Schweikert, E.M.; Devarajan, A.; Witte, I.; Wilgenbus, P.; Amort, J.; Förstermann, U.; Shabazian, A.; Grijalva, V.; Shih, D.M.; Farias-Eisner, R.; et al. PON3 is upregulated in cancer tissues and protects against mitochondrial superoxide-mediated cell death. Cell Death Differ. 2012, 19, 1549-1560. [CrossRef] [PubMed]

197. Kim, E.K.; Choi, E.J. Compromised MAPK signaling in human diseases: An update. Arch. Toxicol. 2015, 89, 867-882. [CrossRef]

198. Baharudin, R.; Ab Mutalib, N.S.; Othman, S.N.; Sagap, I.; Rose, I.M.; Mohd Mokhtar, N.; Jamal, R. Identification of Predictive DNA Methylation Biomarkers for Chemotherapy Response in Colorectal Cancer. Front. Pharmacol. 2017, 8, 47. [CrossRef] [PubMed] 
199. Shui, I.M.; Wong, C.J.; Zhao, S.; Kolb, S.; Ebot, E.M.; Geybels, M.S.; Rubicz, R.; Wright, J.L.; Lin, D.W.; Klotzle, B.; et al. Prostate tumor DNA methylation is associated with cigarette smoking and adverse prostate cancer outcomes. Cancer 2016, 122, 2168-2177. [CrossRef]

200. Cakatay, U.; Kayali, R.; Uzun, H. Relation of plasma protein oxidation parameters and paraoxonase activity in the ageing population. Clin. Exp. Med. 2008, 8, 51-57. [CrossRef] [PubMed]

201. Saruhan, E.; Olgun, A.; Oztürk, K.; Akman, S.; Erbil, M.K. Age-related paraoxonase activity changes in Turkish population. Ann. N Y. Acad. Sci. 2007, 1100, 218-222. [CrossRef]

202. Lescai, F.; Marchegiani, F.; Franceschi, C. PON1 is a longevity gene: Results of a meta-analysis. Ageing Res. Rev. 2009, 8, 277-284. [CrossRef]

203. Rea, I.M.; McKeown, P.P.; McMaster, D.; Young, I.S.; Patterson, C.; Savage, M.J.; Belton, C.; Marchegiani, F.; Olivieri, F.; Bonafe, M.; et al. Paraoxonase polymorphisms PON1 192 and 55 and longevity in Italian centenarians and Irish nonagenarians. A Pool. Anal. Exp. Gerontol. 2004, 39, 629-635. [CrossRef] [PubMed]

204. Goulet, E.D.; Hassaine, A.; Dionne, I.J.; Gaudreau, P.; Khalil, A.; Fulop, T.; Shatenstein, B.; Tessier, D.; Morais, J.A. Frailty in the elderly is associated with insulin resistance of glucose metabolism in the postabsorptive state only in the presence of increased abdominal fat. Exp. Gerontol. 2009, 44, 740-744. [CrossRef]

205. Summerbell, J.; Wynne, H.; Hankey, C.R.; Williams, F.M. The effect of age and frailty upon blood esterase activities and their response to dietary supplementation. Br. J. Clin. Pharmacol. 1993, 36, 399-404. [CrossRef] [PubMed]

206. Bulló, M.; Lamuela-Raventós, R.; Salas-Salvadó, J. Mediterranean diet and oxidation: Nuts and olive oil as important sources of fat and antioxidants. Curr. Top. Med. Chem. 2011, 11, 1797-1810. [CrossRef] [PubMed]

207. Lou-Bonafonte, J.M.; Gabás-Rivera, C.; Navarro, M.A.; Osada, J. PON1 and Mediterranean Diet. Nutrients 2015, 7, 4068-4092. [CrossRef]

208. Loued, S.; Berrougui, H.; Componova, P.; Ikhlef, S.; Helal, O.; Khalil, A. Extra-virgin olive oil consumption reduces the age-related decrease in HDL and paraoxonase 1 anti-inflammatory activities. Br. J. Nutr. 2013, 110, 1272-1284. [CrossRef]

209. Vamecq, J.; Andreoletti, P.; El Kebbaj, R.; Saih, F.E.; Latruffe, N.; El Kebbaj, M.H.S.; Lizard, G.; Nasser, B.; Cherkaoui-Malki, M. Peroxisomal Acyl-CoA Oxidase Type 1: Anti-Inflammatory and Anti-Aging Properties with a Special Emphasis on Studies with LPS and Argan Oil as a Model Transposable to Aging. Oxid. Med. Cell. Longev. 2018, 2018, 6986984. [CrossRef]

210. Cherki, M.; Derouiche, A.; Drissi, A.; El Messal, M.; Bamou, Y.; Idrissi-Ouadghiri, A.; Khalil, A.; Adlouni, A. Consumption of argan oil may have an antiatherogenic effect by improving paraoxonase activities and antioxidant status: Intervention study in healthy men. Nutr. Metab. Cardiovasc. Dis. 2005, 15, 352-360. [CrossRef] [PubMed]

(C) 2019 by the authors. Licensee MDPI, Basel, Switzerland. This article is an open access article distributed under the terms and conditions of the Creative Commons Attribution (CC BY) license (http://creativecommons.org/licenses/by/4.0/). 